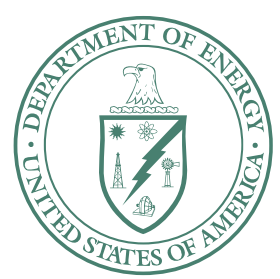

U.S. Department of Energy

Idaho Operations Office

\title{
Integrated Waste Treatment Unit GFSI Risk Management Plan
}

June 2007 
DOE/ID-11270

Revision 1

\section{Integrated Waste Treatment Unit GFSI Risk Management Plan}

June 2007

Prepared by the 


\title{
Integrated Waste Treatment Unit GFSI Risk Management Plan
}

\author{
DOE/ID-11270
}

Revision 1
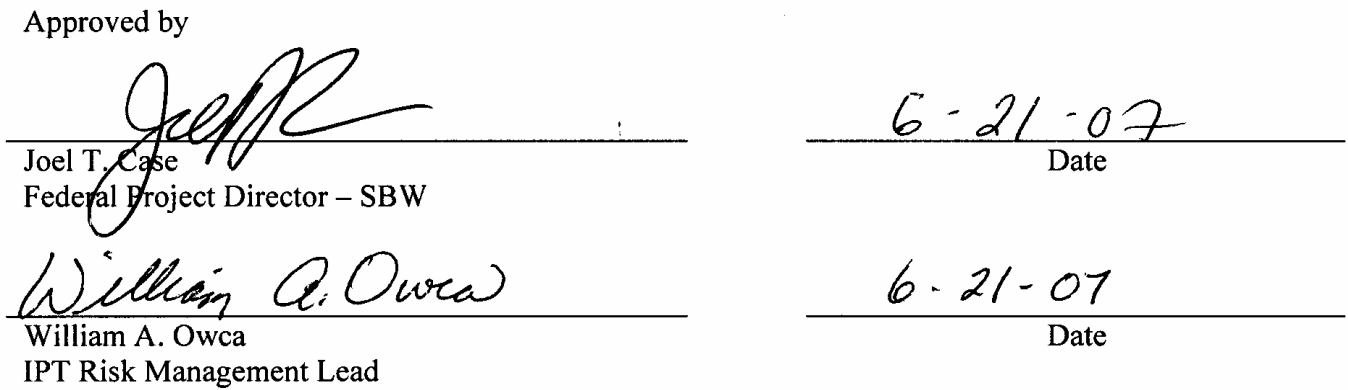

William A. Owca
IPT Risk Management Lead 


\section{CONTENTS}

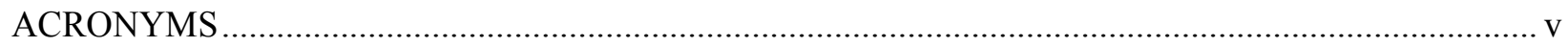

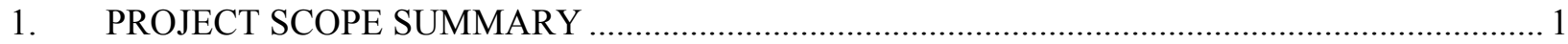

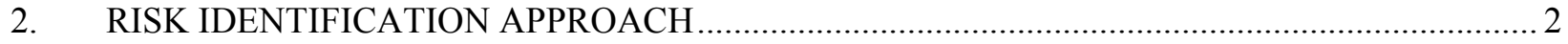

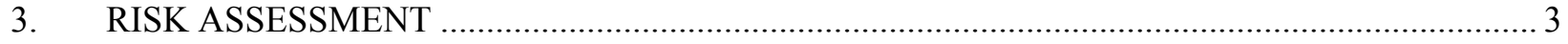

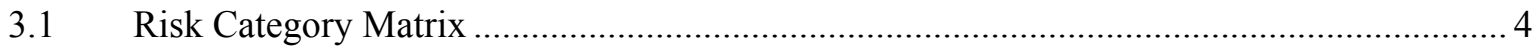

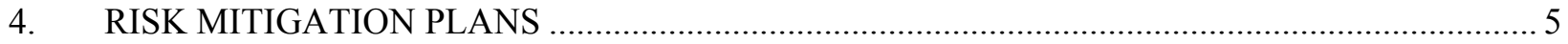

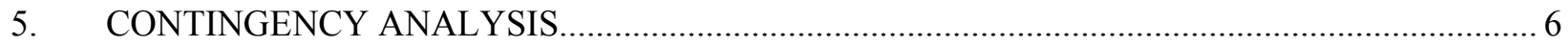

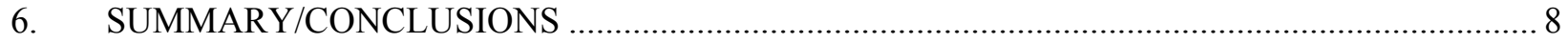

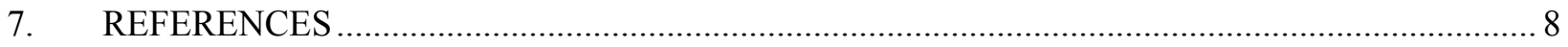

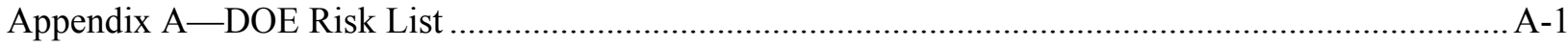

Appendix B —DOE Risk Assessment Forms...................................................................................... B-1

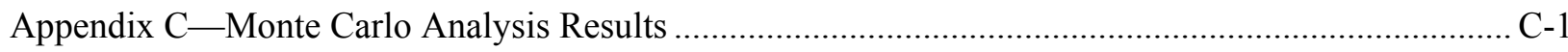

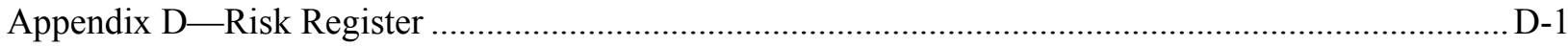

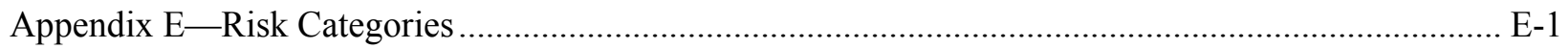

TABLES

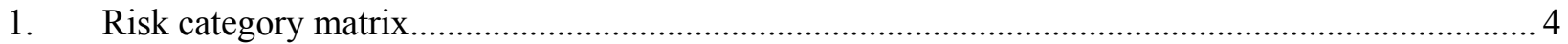




\title{
ACRONYMS
}

\author{
CD Critical Decision \\ CERCLA Comprehensive Environmental Response, Compensation, and Liability Act \\ CRR Carbon Reduction Reformer \\ CWI CH2M-WG Idaho, LLC \\ DMR Denitration Mineralization Reformer \\ DNFSB Defense Nuclear Facilities Safety Board \\ DOE U.S. Department of Energy \\ DOE-HQ U.S. Department of Energy Headquarters \\ DOE-ID U.S. Department of Energy Idaho Operations Office \\ EIR External Independent Review \\ EM Environmental Management \\ ESW early site work \\ GAC granular activated carbon \\ GFSI government-furnished services and items \\ HLW high-level waste \\ ICDF Idaho CERCLA Disposal Facility \\ INTEC Idaho Nuclear Technology and Engineering Center \\ ICP Idaho Cleanup Project \\ IPT Integrated Project Team \\ IWTU Integrated Waste Treatment Unit \\ LI Line Item \\ LLP long-lead procurement \\ MACT Maximum Achievable Control Technology \\ NEPA National Environmental Policy Act \\ NMED New Mexico Environment Department
}




$\begin{array}{ll}\text { NPH } & \text { natural phenomena hazard } \\ \text { NWCF } & \text { New Waste Calcining Facility } \\ \text { OECM } & \text { Office of Engineering and Construction Management } \\ \text { OPC } & \text { Other Project Costs } \\ \text { ORR } & \text { operational readiness review } \\ \text { PDS } & \text { Project Data Sheet } \\ \text { PED } & \text { Project and Engineering Design } \\ \text { PEP } & \text { Project Execution Plan } \\ \text { QA } & \text { quality assurance } \\ \text { RCRA } & \text { Resource Conservation and Recovery Act } \\ \text { RH-TRU } & \text { remote-handled transuranic } \\ \text { RMP } & \text { Risk Management Plan } \\ \text { ROD } & \text { Record of Decision } \\ \text { SASSI } & \text { System Analysis Site-soil Interaction } \\ \text { SAT } & \text { Site Acceptance Test } \\ \text { SBW } & \text { sodium-bearing waste } \\ \text { TSI } & \text { site-soil interaction } \\ \text { TA } & \text { Temporary Authorization } \\ \text { TBD } & \text { to be determined } \\ \text { Thansuranic }\end{array}$




\section{Integrated Waste Treatment Unit GFSI Risk Management Plan}

\section{PROJECT SCOPE SUMMARY}

This GFSI Risk Management Plan (RMP) describes the strategy for assessing and managing project risks for the Integrated Waste Treatment Unit (IWTU) that are specifically within the control and purview of the U.S. Department of Energy (DOE), and identifies the risks that formed the basis for the DOE contingency included in the performance baseline. DOE-held contingency is required to cover cost and schedule impacts of DOE activities.

Prior to approval of the performance baseline (Critical Decision-2) project cost contingency was evaluated during a joint meeting of the Contractor Management Team and the Integrated Project Team for both contractor and DOE risks to schedule and cost. At that time, the contractor cost and schedule risk value was $\$ 41.3 \mathrm{M}$ and the DOE cost and schedule risk contingency value is $\$ 39.0 \mathrm{M}$. The contractor cost and schedule risk value of $\$ 41.3 \mathrm{M}$ was retained in the performance baseline as the contractor's management reserve for risk contingency. The DOE cost and schedule risk value of $\$ 39.0 \mathrm{M}$ has been retained in the performance baseline as the DOE Contingency. The performance baseline for the project was approved in December 2006 (Garman 2006). The project will continue to manage to the performance baseline and change control thresholds identified in PLN-1963, "Idaho Cleanup Project Sodium-Bearing Waste Treatment Project Execution Plan" (PEP).

The Federal Project Director - SBW is the ultimate owner of all DOE Risk. Other project risks related to operations and transportation are not included in this plan, but will be addressed during the operational phase of project implementation. The objective of the RMP is to provide a systematic process for managing the sodium-bearing waste (SBW) IWTU Project government-furnished services and items (GFSI) risks. This RMP will:

- $\quad$ Serve as a basis for identifying strategies to eliminate or reduce impact of GFSI on cost and schedule goals

- Assist in making decisions on budget and funding priorities on DOE contingencies for the project

- Complement the contractor's Risk Management Plan to ensure all risks and contingencies have been properly captured

- $\quad$ Provide risk information for milestone decisions.

The RMP identifies GFSI-related risks and defines strategies for mitigating those risks. In addition, contingency is analyzed and tabulated to compare current cost and schedule risks against the Project Data Sheet. Evaluated risks are listed on the Risk List in Appendix A. Appendix B contains the detailed risk assessment forms for each risk, and Appendix C contains the Monte Carlo reports that support the contingency analysis for the project. Appendix D is the project Risk Register and Appendix E are the risk categories. This revision reflects the project risks for Critical Decision-3..

This RMP will be updated prior to each critical decision, biannually, or more often if new risks are identified and are of magnitudes that require action by the Integrated Project Team (IPT). CD-2 approval is a commitment by DOE to the projects performance baseline. However, project risks may ultimately preclude success of the baseline, requiring implementation of a performance alternative. The IPT will 
regularly evaluate project risks, and if it becomes apparent that the performance baseline cannot be achieved, then management will be notified and alternative solutions will be identified.

The project has identified two high-risk issues and has developed a strategy to mitigate the risks in accordance with Action Memorandum, Request for Approval of the Sodium Bearing Waste Treatment Project Path Forward to Mitigate Project Risk Consistent with existing CD-1 Authorization (DOE 2006).

The first issue involves uncertainty regarding disposal of the treated SBW at the Waste Isolation Pilot Plant (WIPP). DOE is responsible for providing a viable disposal pathway as Government Furnished Services/Items. A DOE waste determination for SBW is needed to allow SBW treated product disposal at WIPP. However, the SBW may not meet the WIPP waste acceptance criteria due to the presence of a small volume (approximately 7\%) of reprocessing waste commingled with the SBW. Absent a transuranic (TRU) waste determination, SBW would not be allowed to be disposed of in WIPP. Although SBW has not been considered high-level waste by DOE for at least 10 years, recent legal actions, associated with DOE Order 435.1 waste classifications, have impeded DOE's ability to formally determine that SBW is remote-handled, transuranic waste and make SBW eligible for disposal at WIPP. To address the risk, the treatment facility is being designed and constructed so it could be converted to treat the waste for alternate waste disposal at Yucca Mountain if needed. Additional pilot plant testing was conducted to evaluate waste form performance relative to the Yucca Mountain waste acceptance criteria.

Although the treatment facility is being designed and constructed so it could be converted to treat the waste for alternate waste disposal at Yucca Mountain, if needed, and the pilot plant testing has been completed; the cost and schedule impacts of this risk represent a potentially fatal impact to meeting the performance baseline because it exceeds available contingency and entirely changes the complexion of the IWTU Project. Therefore, risk IWTU-DOE-002 "SBW is determined to be HLW" has been removed from the Monte Carlo Analysis. The project is baselined on WIPP waste acceptance.

Although removed from the Monte Carlo Analysis, the Project will continue to track and monitor this risk. Evaluation of the worst case, should this risk be realized, is $\$ 100 \mathrm{M}$ capital cost plus 12 months schedule delay. Several mitigation actions for the waste determination risk have been undertaken by the project, including supporting DOE Headquarters in establishing a coordinated schedule for TRU waste determination criteria, individual TRU waste determinations, and a Class 3 permit modification submittal. In addition to these programmatic actions, the project is incorporating hardware modifications to the IWTU that would enable cost-effective implementation of the mineralization flowsheet that would result in a robust, treated-product waste form. These mitigation actions and an ongoing participation in the TRU waste determination process will enable the project to stay abreast of the waste determination status and effectively identify to DOE management if this risk becomes fatal to the performance baseline.

The second issue regards a potential future mission for the facility. Approximately 4,400 cubic meters of calcine high-level waste (HLW) is planned for direct packaging and disposal at Yucca Mountain by 2035 . However, calcine may need further processing to meet the Yucca Mountain waste acceptance criteria. To address this risk, the treatment facility is being designed and constructed so it could be converted for calcine treatment if needed. Increased process cell vault shielding and seismic protection have been incorporated into the design to address this risk.

\section{RISK IDENTIFICATION APPROACH}

A risk is defined as an external circumstance or event that must not occur for the project to be successful. If such an event is likely to happen, then it would be a risk. Identifying something as a risk increases its visibility, and allows proactive risk management techniques to be put into place. Project risks 
include any condition that could cause the project to negatively deviate from its required safety performance, specified quality levels, baseline cost, scope, or schedule.

The Risk Register (Appendix D) is a forward-looking compilation of all risks documented during the risk identification, or brainstorming phase, of risk planning. The Risk Register is an Excel database that is maintained by the contractor for the entire SBW Project and is used for gathering all potential emerging risks as they arise. As risks are identified, they are added to the Risk Register. The following steps are used to complete the Risk Register:

\section{Record risk scenario}

2. Identify risk(s) to the project based on the scenario (example - critical path slippage)

3. Assign risk category (see Appendix E)

4. Assign risk sub-category (see Appendix E)

5. Record any assumptions (circumstances or events the project team believes will occur based on the scenario)

6. Record any uncertainties (unknowns related to assumptions and/or the scenario that may cause the risk to be realized).

Lessons learned and team experience provide a sound basis for risk identification. The IPT, consisting of DOE Idaho Operations Office (DOE-ID) and contractor staff, was assembled to identify and evaluate GFSI and associated risks. The IPT is defined in the Project Execution Plan (PLN-1963). The team used a structured approach to identify and analyze those GFSI processes and products that are critical to meeting project objectives. Through multiple meetings, the IPT determined the risk probability, the risk impact, and the strategy to address the risk. The risk information is recorded in a standard Risk Assessment Form. Risk information will be included in all project reviews, and as new risks are identified they will be documented. The SBW Federal Project Director will conduct additional reviews as necessary to evaluate and mitigate future risks that could adversely affect the project.

Risks may be identified by the IPT, or by any individual associated with the project, including DOE and contractors. Individuals involved in the detailed and day-to-day technical, cost, and scheduling aspects are most aware of the potential problems (risks) to be managed. The IPT has compared the GFSI identified risks with the contractor's risk management plan, PLN-1973, "Integrated Waste Treatment Unit Risk Management Plan," to ensure that risks are clearly defined, distinct, and not redundant or overlapping. As a result, two distinct lists of risks have been identified, evaluated, and documented; one for GFSI, which is the subject of this document, and one for contractor risk, which is documented in the contractor's RMP.

\section{RISK ASSESSMENT}

Once risks and opportunities have been identified, the IPT then categorize the identified risks by probability and severity (consequences) of impact as outlined below.

\section{Risk Event Probability}

- Very Unlikely: The risk event is very unlikely to occur in the life of the project. If we ran this project a hundred times, it would not be expected to occur once. 
- Unlikely: The risk event might occur once if we ran this project 10 times, but is unlikely to occur during this project.

- $\quad$ Possible: The risk event could occur once during the project.

- $\quad$ Likely: The risk event is likely to occur at least once during the project. More often than not, on a similar project, it will occur.

- $\quad$ Very Likely: The risk event is very likely to occur at least once and probably will occur multiple times. It is likely that it will occur during the life of the project.

\section{$\underline{\text { Risk Event Severity }}$}

- Very Low: Safety, cost, and/or schedule impact would be insignificant, very little impact on scope and quality issues would barely be noticeable.

- Low: Safety, cost, and/or schedule impact would be less than 5\% (total project), scope would be affected in only minor areas or the quality impact would be noticeable in only the most demanding applications.

- Moderate: Safety, cost, and/or schedule impacts would be in the 5\% to $10 \%$ range (total project), major areas of scope would be affected or quality reductions would require DOE approval.

- $\quad$ High: Safety, cost, and/or schedule impacts would be in the $10 \%$ to $20 \%$ range, scope impacts would be unacceptable to the DOE or quality impacts would be unacceptable to the DOE.

- Very High: Safety, cost, and/or schedule impacts would be greater than $20 \%$ or the project deliverable is effectively useless or unusable.

Therefore the most serious risks (Very High Risk) would have a "Very Likely" probability of occurrence with "Very High" severity (consequences).

\subsection{Risk Category Matrix}

The IPT shall utilize judgment and experience to evaluate each risk element and assess its severity and probability. As shown in the table Risk Category Matrix below (Table 1), for each event, the team must categorize each risk based on its severity and probability resulting in Risk Categories from Very Low Risk to Very High Risk as explained below.

Table 1 . Risk category matrix.

\begin{tabular}{lccccc}
\hline Probability/Severity & Very Low & Low & Moderate & High & Very High \\
\hline Very Likely & M & H & H & VH & VH \\
Likely & M & M & H & H & VH \\
Possible & L & M & M & H & H \\
Unlikely & VL & L & M & M & H \\
Very Unlikely & VL & VL & L & M & H \\
\hline
\end{tabular}




\section{$\underline{\text { Risk Categories }}$}

- $\quad$ Very Low Risk: Normal management practices are sufficient.

- Low Risk: Normal management practices should be sufficient, but project team awareness should be maintained.

- $\quad$ Moderate Risk: Project team should consider each risk event and should exercise their best judgment. Strong consideration should be given to address the risk elements in the Risk Management Plan with actions deemed appropriate by the project team.

- $\quad$ High Risk: The project team shall perform sufficient analysis to assure the event is understood and appropriate action(s) identified. Risk handling actions are mandatory and shall be addressed in the Risk Management Plan. Continual tracking of these risks and their associated actions is appropriate.

- $\quad$ Very High Risk: The project team shall perform sufficient analysis to assure the event is understood and appropriate mitigation(s) identified. Risk handling actions are mandatory and shall be addressed in the Risk Management Plan. Continual tracking of these risks and their mitigating actions is essential.

Risk Assessment Forms shall be prepared for each risk evaluated and included in Appendix B of this Risk Management Plan.

\section{RISK MITIGATION PLANS}

A risk management approach (mitigation plan) is developed for each "Moderate," "High," and "Very High" risk element and documented on the Risk Assessment Forms.

Risk Mitigation Plans are identified on the Risk Assessment Forms in Appendix B. The probability, consequences, and risk levels identified on the Risk Form are the residual values assuming mitigation actions are effective. For "Low" and "Very Low" risk elements and "Moderate" risk elements not judged to require documented mitigation plans, the SBW Federal Project Manager may use normal management functions and work processes to control risk mitigation.

Risk Mitigation Plans should be produced with the participation of the IPT utilizing the "what if" approach. Mitigation could be as simple as seeing that an executive-level relationship is established with Environmental Management (EM), to as complex as replanning a project activity to maintain adequate schedule float. General categories to mitigate risk are as follows:

- $\quad$ Avoidance

- Reduction

- Transfer

- $\quad$ Sharing

- $\quad$ Acceptance and Management

- Insurance. 
Response to risk should fall within these categories but actions required in the mitigation plans should be more specific. Mitigation plans included in Appendix B were developed by the IPT and represent DOE efforts to ensure that technical and programmatic risks do not delay the project or result in additional cost.

\section{CONTINGENCY ANALYSIS}

Project contingency was evaluated by the IPT for both contractor and DOE risks to schedule and cost. The contractor's Risk Management Plan assesses the contractor risks. The DOE GFSI risks are evaluated in this document.

Schedule risks were evaluated in both days and related costs. For each schedule risk, the time when the risk was expected to occur was identified and an anticipated project baseline cost for that time was applied. The basis column in the Risk List (Appendix A) defines the project baseline cost applied for each schedule risk.

The hotel load used in the risk management process was determined by evaluating the potential scenarios that may be faced as various risks occur. Fiscal years FY-07 - FY-09 contain the majority of project costs with only a minor component left in FY-10 as the project winds down in the first quarter of that year. Taking the 3 key years for fabrication, construction, and testing there is a direct total project cost of $\$ 188 \mathrm{M}$. Divide that by 36 months and you arrive at an average $\$ 5.2 \mathrm{M}$ per month in the project burn rate.

In this risk management plan when schedule delays were considered, they were limited to impacts on the critical path. As the Integrated Project Team (IPT) evaluated each risk, they considered various alternatives to employ for risks that occur. The evaluation provided an impact to the critical path for each risk. By limiting schedule impacts to those that hit the critical path, determining the hotel load becomes an evaluation of overall impacts to the project vs. individual impacts to multiple disciplines.

In considering the burn rate of $\$ 5.2 \mathrm{M}$ (direct - without G\&A), two factors influence the final hotel load. First, material costs are not a factor in the hotel load. Accordingly material costs are deducted from the burn rate. Secondly, if the delay is long enough, construction labor would be turned down until the risk response actions were completed. For this hotel load determination the project has decided to use 30 days as the break point for reducing construction labor costs. If a risk takes longer than 30 days, then the construction labor costs are deducted from the burn rate.

To adjust the burn rate down to an appropriate hotel load, the material costs were determined to be $12.6 \%$ of the direct TPC. For risks less than 30 days in duration, the hotel load is $\$ 5.2 \mathrm{M}-\$ 0.6 \mathrm{M}=$ $\$ 4.6 \mathrm{M} /$ month. For those risks longer than 30 days, an additional reduction in the construction labor costs is added. Construction labor costs were determined to be $16.4 \%$ of the direct TPC. For risks longer than 30 days, the hotel load is $\$ 5.2 \mathrm{M}-\$ 1.5 \mathrm{M}=\$ 3.7 \mathrm{M} /$ month.

The IPT uses an $80 \%$ confidence level of the combined schedule and cost values to measure risk contingency values. Prior to approval of the performance baseline (Critical Decision-2) project cost contingency was evaluated during a joint meeting of the Contractor Management Team and the Integrated Project Team for both contractor and DOE risks to schedule and cost. At that time, the contractor cost and schedule risk value was $\$ 41.3 \mathrm{M}$ and the DOE cost and schedule risk contingency value was $\$ 39.0 \mathrm{M}$. The contractor cost and schedule risk value of $\$ 41.3 \mathrm{M}$ was retained in the performance baseline as the contractor's management reserve for risk contingency. The DOE cost and schedule risk value of $\$ 39.0 \mathrm{M}$ has been retained in the performance baseline as the DOE Contingency. The performance baseline for the project was approved in December 2006 (Garman 2006). The project will continue to manage to the 
performance baseline and change control thresholds identified in PLN-1963, "Idaho Cleanup Project Sodium-Bearing Waste Treatment Project Execution Plan."

Prior to approval of construction (Critical Decision-3) project cost contingency was evaluated during a joint meeting of the Contractor Management Team and the Integrated Project Team for both contractor and DOE risks to schedule and cost. At CD-3, the contractor cost and schedule risk value was $\$ 32.8 \mathrm{M}$ and the DOE cost and schedule risk contingency value is $\$ 39.6 \mathrm{M}$.

Prior to approval of the performance baseline (Critical Decision-2), the schedule contingency values for the contractor and DOE were 197 and 221 days respectively. These risks occur concurrently. Evaluating the worst case 221-day impact indicated about 7 months were needed in schedule contingency. Per DOE O 413.3A and the External Independent Review Team's recommendations, the 7 months of schedule contingency were added to the end of the last critical path activity, Critical Decision-4. However, given the nature of the ICP contract, the project working schedule remained unchanged (CD-4:12/09) and the schedule contingency was reflected in the Project Data Sheet and approved schedule baseline in PLN-1963, "Idaho Cleanup Project Sodium-Bearing Waste Treatment Project Execution Plan.”.

Prior to approval of construction (Critical Decision-3) the schedule contingency values for the contractor and DOE are 134 and 231 days respectively. These risks occur concurrently.

The approach to developing cost contingency for residual risk impacts identifies probabilities of variance for each cost element impacted, and for factors that are global, such as labor productivity, as applicable. Prior to application of contingency, the confidence level(s) of a residual risk cost estimate are obtained by running a risk assessment simulation. Contingency is established using this Monte Carlo simulation model (Appendix C). Monte Carlo analysis is a quantitative simulation technique involving the following steps:

- The first step is to develop a capital cost estimate.

- $\quad$ The second step is to identify the Best Case, Worst Case, and Most Likely probability ranges.

- The third step is to analyze the estimate with simulation.

- $\quad$ Finally, all the risks are considered in an integrated fashion with ICP management and the SBW IPT to determine the contractor management reserve amount and the DOE contingency for the project (captured on the PDS).

All data used in the Monte Carlo simulation runs come from the Integrated Project Team in its risk review sessions. The data is constructed from subject matter judgment and consensus review by the team. In general, probability distribution curves are developed for each risk using the best case, most likely, and worst case values. When the most likely value is toward the middle of the range, a triangle distribution curve is used. In cases where the most likely value tends toward either the best case or worst case value a beta distribution curve is used. Given the subjective nature of risk evaluations, no hard and fast rules for beta distribution input have been established. However, the beta curve is adjusted so the curve represents the best judgment of the risk team relative to best case, most likely, and worst case values. Minor adjustments to Monte Carlo input that may be more precise have little effect on the final risk value when an $80 \%$ confidence level is used.

Relative to schedule analysis, a Monte Carlo simulation provides recommended schedule contingency for various levels of confidence. Typically, DOE projects look for $80 \%$ confidence added to the schedule. Three activity duration values (optimistic, most likely, pessimistic) form the basic input for 
the analysis (Appendix C). Just as in the cost analysis, the schedule contingency is considered in an integrated fashion with the ICP schedule.

Another approach to schedule contingency may be as simple as adding resources, replanning work, and constructability review and implementation.

\section{SUMMARYICONCLUSIONS}

Since the start of the project, ten DOE-owned risks have been identified by the IPT and are summarized in Appendix A. Five of these risks have been mitigated, accepted, or removed from the analysis because they are outside the scope of the project. Risk mitigation plans have been developed and are being implemented for each of the five remaining DOE-owned risks. The Monte Carlo based simulations generated a most likely cost risk of $\$ 39.6 \mathrm{M}$, and a most likely schedule risk of 231 days.

\section{REFERENCES}

10 CFR 851, 2006, "Worker Safety and Health Programs," Code of Federal Regulations, Office of the Federal Register, November 30, 2006.

70 FR 242, 2005, "Record of Decision for the Idaho High-Level Waste and Facilities Disposition Final Environmental Impact Statement," Federal Register, U.S. Department of Energy,

pp. 75165-75172, December 19, 2005.

DNFSB 2004-2, Active Confinement Systems, with Technical Report DNFSB/TECH-34, Confinement of Radioactive Materials at Defense Nuclear Facilities, Recommendation 2004-2, Defense Nuclear Facilities Safety Board, December 7, 2004.

DOE, 2006, Request for Approval of the Sodium-Bearing Waste Treatment Project Path Forward to Mitigate Project Risk Consistent with existing CD-1 Authorization, DOE Action Memorandum, James A. Rispoli, February 27, 2006.

DOE G 420.1-1, 2000, "Nonreactor Nuclear Safety Design Criteria and Explosive Safety Criteria Guide for use with DOE O 420.1 Facility Safety," U.S. Department of Energy, March 28, 2000.

DOE O 413.3A, 2006, "Program and Project Management for the Acquisition of Capital Assets," U.S. Department of Energy, July 28, 2006.

DOE O 435.1, 2001, "Radioactive Waste Management," Change 1, U.S. Department of Energy, August 28, 2001.

Garman, David K., DOE Headquarter, to Joel T. Case, DOE Idaho Operations Office, December 29, 2006, “Approval of Performance Baseline (Critical Decision-2) and the Associated Baseline Change Proposal, Long Lead Procurements and Site Preparation (Critical Decision-3B), and the Project Execution Plan for the Sodium-Bearing Waste Treatment Project."

ISA-84.00.01, 2004, "Functional Safety: Safety Instrumented Systems for the Process Industry Sector," ANSI/ISA-84.00.01-2004, The Instrumentation, Systems, and Automation Society, September 2, 2004.

PLN-1963, 2007, "Idaho Cleanup Project Sodium-Bearing Waste Treatment Project Preliminary Project Execution Plan,” Rev. 2, Idaho Cleanup Project, April 5, 2007. 
PLN-1973, 2007, “Integrated Waste Treatment Unit Risk Management Plan,” Rev. 7 Draft, Idaho Cleanup Project, June 2007. 


\section{Appendix A}

\section{DOE Risk List}




$$
\text { A-2 }
$$




\section{Appendix A}

DOE Risk List

\begin{tabular}{|c|c|c|c|c|c|c|c|c|c|c|c|}
\hline & Description & $\mathbf{P}$ & C & L & Best \$K & $\begin{array}{c}\text { Most } \\
\text { Likely } \\
\$ K\end{array}$ & $\begin{array}{c}\text { Worst } \\
\$ K\end{array}$ & $\begin{array}{l}\text { Best } \\
\text { time } \\
\text { (days) }\end{array}$ & $\begin{array}{l}\text { Most } \\
\text { Likely } \\
\text { Time }\end{array}$ & $\begin{array}{c}\text { Worst } \\
\text { time }\end{array}$ & Basis \\
\hline DOE-005 & $\begin{array}{l}\text { DOE-005 DOE Operational Readiness Review delays } \\
\text { approval of start of operations }\end{array}$ & L & $\mathrm{L}$ & $\mathrm{M}$ & 0 & 4,600 & 11,100 & 0 & 30 & 90 & $\begin{array}{l}\text { ML } \$ 4.6 \mathrm{M} / \mathrm{mon} \text { Hotel Load ( } 0-30 \text { days) WC } \\
\$ 3.7 \mathrm{M} / \mathrm{mon} \text { Hotel Load }(30+\text { days) }\end{array}$ \\
\hline DOE-007 & $\begin{array}{l}\text { DOE-007 DNFSB 2004-2 implementation for active } \\
\text { ventilation system }\end{array}$ & $\mathrm{U}$ & VH & $\mathrm{H}$ & 0 & 0 & 50,900 & 0 & 0 & 210 & $\begin{array}{l}\text { WC } \$ 25 \mathrm{M} \text { cost plus } \$ 3.7 \mathrm{M} / \mathrm{mon} \text { Hotel Load } \\
(30 \text { + days })\end{array}$ \\
\hline DOE-009 & Post Seismic Monitoring capability is required & $P$ & $\mathrm{~L}$ & $\mathrm{M}$ & 0 & 0 & 17,800 & 0 & 0 & 120 & $\begin{array}{l}\text { WC } \$ 3 \mathrm{M} \text { cost plus } \$ 3.7 \mathrm{M} / \mathrm{mon} \text { Hotel Load }(30+ \\
\text { days) }\end{array}$ \\
\hline DOE-010 & $\begin{array}{l}\text { Full Application of ISA } 84.00 .01 \text { is required for the IWTU } \\
\text { control System }\end{array}$ & P & $\mathrm{M}$ & $\mathrm{M}$ & & & 25,200 & & & 180 & $\begin{array}{l}\text { WC } \$ 3 \mathrm{M} \text { cost plus } \$ 3.7 \mathrm{M} / \mathrm{mon} \text { Hotel Load }(30+ \\
\text { days) }\end{array}$ \\
\hline
\end{tabular}

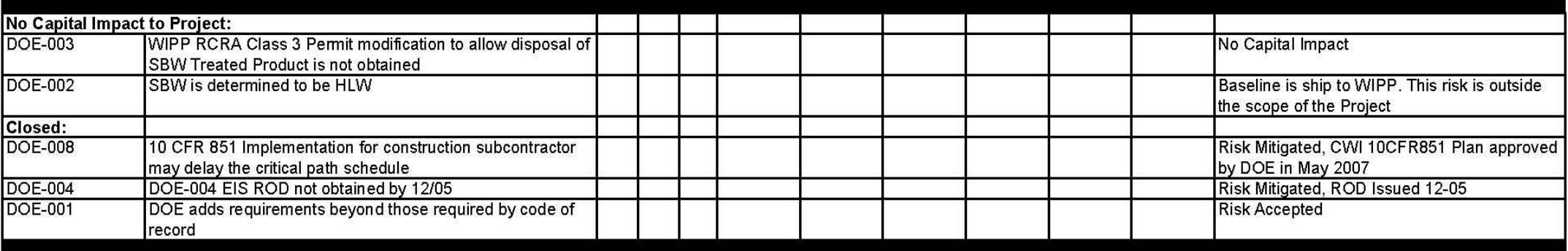

\begin{tabular}{|c|c|c|c|c|c|c|c|}
\hline & $\begin{array}{c}\text { Best Cost } \\
\text { and } \\
\text { Schedule } \\
\$ K\end{array}$ & $\begin{array}{c}\text { Most } \\
\text { Likely } \\
\text { Cost and } \\
\text { Schedule } \\
\text { \$K } \\
\end{array}$ & $\begin{array}{c}\text { Worst } \\
\text { Cost and } \\
\text { Schedule } \\
\text { \$K } \\
\end{array}$ & $\begin{array}{c}\text { Best } \\
\text { Schedule } \\
\text { Days }\end{array}$ & $\begin{array}{c}\text { Most } \\
\text { Likely } \\
\text { Schedule } \\
\text { Days } \\
\end{array}$ & $\begin{array}{c}\text { Worst } \\
\text { Schedule } \\
\text { Days }\end{array}$ & \\
\hline Forecasts: & 0 & 9,200 & 116,100 & 0 & $\begin{array}{r}60 \\
\end{array}$ & $\begin{array}{r}690 \\
\end{array}$ & \\
\hline
\end{tabular}

Legend:

$\mathbf{P}$ - Probability

$\mathrm{C}$ - Consequence

L - Risk Level (Probability x Consequence)

$\mathrm{H}$ - High

P - Probable

M-Medium

L - Low

U - Unlikely 
Appendix B

\section{DOE Risk Assessment Forms}


B-2 


\section{RISK ASSESSMENT FORM}

Risk \# IWTU-DOE-001

Risk Title: External - DOE adds requirements beyond those required by Code of Record

\section{A. Statement of Risk CLOSED - RISK ACCEPTED, EM-1 APPROVED PATH FORWARD ACTION MEMORANDUM ON FEBRUARY 27, 2006. MEMORANDUM CONFIRMED FACILITY PERFORMANCE CATEGORIZATION.}

Requirements beyond those required in the ICP-DOE contract may be imposed by DOE on the ICP contractor.

\section{B. Assumptions}

Although DOE reviews during development of the design occur and have so far proven to be effective, additional requirements may arise later in the life of the project.

\section{Uncertainties}

None

D. Probability

$\square$ Very Unlikely $\square$ Unlikely $\square$ Possible $\square$ Likely $\square$ Very Likely

\section{E. Consequences}

Depending on the project design and/or construction stage the impacts may range up to high.

\begin{tabular}{|l|l|l|l|}
\hline & Cost & Schedule & Comments \\
\hline Best & & & \\
\hline Most Likely & & & \\
\hline Worst & & & \\
\hline
\end{tabular}

$\square$ Very Low $\square$ Low $\square$ Moderate $\square$ High $\square$ Very High

F. Risk Level

$\square$ Very Low $\square$ Low $\square$ Moderate $\square$ High $\square$ Very High

G. Comments

Final decisions concerning applicable standards and orders should be achieved at the time of CD-2 approval. Schedule delays would be incurred while the analysis and any subsequent change actions occur.

Risk is accepted. Mitigation actions (see below), including implementation of the Regulatory Uncertainty Mitigation Strategy, reduced the risk. However, a long-term risk of changes to the Code of Record and/or legal requirements still exists. As specific risks are identified, they will be evaluated. 
H. Mitigation Plan

\begin{tabular}{|l|l|l|l|}
\hline \multicolumn{1}{|c|}{ Mitigation Actions } & \multicolumn{1}{|c|}{$\begin{array}{c}\text { Scheduled } \\
\text { Implementation }\end{array}$} & Responsibility & \multicolumn{1}{|c|}{ Current Status } \\
\hline $\begin{array}{l}\text { Plan to freeze requirements, codes, and standards } \\
\text { when CD-2 is approved }\end{array}$ & SEP 7,2006 & $\begin{array}{l}\text { Joel Case / } \\
\text { Keith Lockie }\end{array}$ & $\begin{array}{l}\text { Complete - LST- } \\
\text { 22-002 issued }\end{array}$ \\
\hline $\begin{array}{l}\text { EM-1 approved Path Forward Action Memorandum } \\
\text { on February 27, 2006. Memorandum confirmed } \\
\text { Facility Performance Categorization. }\end{array}$ & FEB 27, 2006 & $\begin{array}{l}\text { Joel Case / } \\
\text { Keith Lockie }\end{array}$ & Complete \\
\hline $\begin{array}{l}\text { DNFSB briefed on March 3, 2006, regarding safety } \\
\text { basis approach. EM-1 Letter to DNFSB } \\
\text { documenting results of briefing will be submitted by } \\
\text { April 1, 2006. }\end{array}$ & APR 1, 2006 & $\begin{array}{l}\text { Joel Case / } \\
\text { Keith Lockie }\end{array}$ & Complete \\
\hline $\begin{array}{l}\text { Continue engagement of DOE-HQ and EM-3 to } \\
\text { resolve safety basis approach for IWTU. Weekly } \\
\text { teleconferences are held with EM-3 to work hazard } \\
\text { categorization and performance category approach. }\end{array}$ & MAR 15,2006 & Joel Case & Complete 3/15/06 \\
\hline $\begin{array}{l}\text { PDSA is scheduled to be approved by DOE-ID } \\
\text { April 20, 2006. }\end{array}$ & APR 20,2006 & Joel Case & Complete 5/26/05 \\
\hline $\begin{array}{l}\text { The final determination of hazard categorization and } \\
\text { performance categorization will be completed by } \\
\text { April 20, 2006. }\end{array}$ & APR 20,2006 & Joel Case & Complete 3/23/06 \\
\hline
\end{tabular}




\section{RISK ASSESSMENT FORM}

Risk \# IWTU-DOE-002

Risk Title: External - SBW is determined to be HLW.

A. Statement of Risk - RISK IS NOT EVALUATED IN THE MONTE CARLO ANALYSIS AS IT IS OUTSIDE THE SCOPE OF THIS PROJECT.

A DOE waste determination for sodium bearing waste is needed to allow SBW Treated product disposal at WIPP. Absent a TRU waste determination, SBW would not be allowed to be disposed in WIPP.

\section{B. Assumptions}

SBW will be determined to be TRU Waste and will be disposed at WIPP.

C. Uncertainties

The outcome of the DOE-HQ Waste Determination.

D. Probability

$\square$ Very Unlikely $\square$ Unlikely $\square$ Possible $\square$ Likely $\square$ Very Likely

\section{E. Consequences}

If the SBW is determined to be HLW, the decisions will not be made until FY 2009. The Project conducted pilot plant testing for a mineralized waste form. In the event the SBW is determined to be HLW the project would be re-baselined.

\begin{tabular}{|l|l|l|l|}
\hline & Cost & Schedule & Comments \\
\hline Best & & & \\
\hline Most Likely & & & \\
\hline Worst & & & \\
\hline
\end{tabular}

$\square$ Very Low $\square$ Low $\square$ Moderate $\square$ High $\square$ Very High

F. Risk Level

$\square$ Very Low $\square$ Low $\square$ Moderate $\square$ High $\square$ Very High

G. Comments

This Risk is not evaluated in the Monte Carlo Analysis as it is outside the scope of this project.

H. Mitigation Plan

\begin{tabular}{|l|l|l|l|}
\hline \multicolumn{1}{|c|}{ Mitigation Actions } & \multicolumn{1}{c|}{$\begin{array}{c}\text { Scheduled } \\
\text { Implementation }\end{array}$} & Responsibility & \multicolumn{1}{|c|}{ Current Status } \\
\hline $\begin{array}{l}\text { EM-HQ develop draft Waste Determination } \\
\text { Criteria for TRU Tank Waste Disposal at WIPP, in } \\
\text { coordination with Idaho and ORP. }\end{array}$ & OCTOBER, 2007 & Keith Lockie & Ongoing \\
\hline $\begin{array}{l}\text { EM-HQ determine public review process for } \\
\text { criteria acceptance. }\end{array}$ & $\begin{array}{l}\text { DECEMBER, } \\
2007\end{array}$ & Keith Lockie & Ongoing \\
\hline $\begin{array}{l}\text { EM-HQ complete public review process for Waste } \\
\text { Determination Criteria. }\end{array}$ & JUNE, 2008 & Keith Lockie & Planned \\
\hline DOE-ID draft SBW Waste Determination. & OCTOBER, 2008 & Keith Lockie & Planned \\
\hline EM-HQ issue SBW Waste Determination. & $\begin{array}{l}\text { DECEMBER, } \\
\text { 2008 }\end{array}$ & Keith Lockie & Planned \\
\hline
\end{tabular}




\section{RISK ASSESSMENT FORM}

Risk \# IWTU-DOE-003
Risk Title: External - WIPP RCRA Class 3 Permit modification to allow disposal of SBW Treated Product is not obtained.

\section{A. Statement of Risk: Future Consideration - no impact to capital project}

The Department's preferred disposal path for this waste is WIPP. The Department will perform a waste determination and pursue the appropriate regulatory approvals from EPA and the New Mexico Environment Department, to allow disposal of the sodium-bearing waste to WIPP. Until such time as the waste determination is made and the regulatory approvals are obtained, the Department will manage the waste to permit disposal at WIPP or at the repository planned for Yucca Mountain. However, if DOE makes a formal Waste Determination, the approval to ship the solidified SBW Treated Product may be delayed by EPA or the State of New Mexico.

\section{B. Assumptions}

1. This risk is outside the Capital Project therefore there is no risk to the Capital Project,

2. The Project needs to continue to work to obtain the permit in time to complete the transfer of the waste product to WIPP by September 2012.

\section{Uncertainties}

Political and Regulatory environments are uncertain at this time.

\section{Probability}

Although a formal waste determination is necessary, other regulatory and legal issues may delay SBW Treated Product disposal at WIPP
Very Unlikely
Unlikely
Possible
Likely
Very Likely

\section{E. Consequences}

If the WIPP RCRA Class 3 Permit modification is not obtained, ICP contract adjustments would be needed. However, tank closure and liquid waste treatment could still be achieved. Treated waste would be safely stored in $\mathrm{RH}$-canisters in the constructed storage vaults. A decision on ultimate disposal could be deferred until the permit issue is resolved.

\begin{tabular}{|l|l|l|l|}
\hline & Cost & Schedule & Comments \\
\hline Best & & & \\
\hline Most Likely & & & \\
\hline Worst & & & \\
\hline
\end{tabular}

$\square$ Very Low $\square$ Low $\square$ Moderate $\square$ High $\square$ Very High

F. Risk Level

$\square$ Very Low $\square$ Low $\square$ Moderate $\square$ High $\square$ Very High

\section{G. Comments}

This risk is not evaluated in the Monte Carlo Analysis as it is outside the scope of the Capital Project. Work closely with WIPP to satisfy regulatory issues and needs. DOE-HQ is developing a coordinated schedule for TRU Waste Determination criteria, individual TRU Waste Determinations, and Class 3 PMR submittals. 
H. Mitigation Plan -

\begin{tabular}{|l|l|l|l|}
\hline \multicolumn{1}{|c|}{ Mitigation Actions } & \multicolumn{1}{|c|}{$\begin{array}{c}\text { Scheduled } \\
\text { Implementation }\end{array}$} & Responsibility & \multicolumn{1}{|c|}{ Current Status } \\
\hline $\begin{array}{l}\text { Following issuance of the SBW Waste } \\
\text { Determination (See DOE-002 Mitigation Strategy) } \\
\text { coordinate with CFBO, Class III Permit }\end{array}$ & DECEMBER & Jerry Wells & Ongoing \\
$\begin{array}{l}\text { Modification request to allow acceptance of INTEC } \\
\text { Tank Farm Waste Product (SBW) at WIPP. }\end{array}$ & & & \\
\hline $\begin{array}{l}\text { Coordinate NMED review and approval of Class } \\
\text { III Permit Modification request. }\end{array}$ & $\begin{array}{l}\text { DECEMBER, } \\
\text { 2010 }\end{array}$ & Jerry Wells & Ongoing \\
\hline
\end{tabular}




\section{RISK ASSESSMENT FORM}

Risk \# IWTU-DOE-004

December 2005

Risk Title: External - EIS Record of Decision not achieved by

\section{A. Statement of Risk: CLOSED - RISK MITIGATED}

A Record of Decision for the 2002 HLW EIS is necessary to proceed with the steam reformer treatment option for SBW.

\section{B. Assumptions}

None

\section{Uncertainties}

None

D. Probability

Delay of the ROD is possible
Very Unlikely
Unlikely
Possible $\square$ Likely
Very Likely

E. Consequences

Ability to meet project schedule objectives will be severely impacted depending on the time delay.

\begin{tabular}{|l|l|l|l|}
\hline & Cost & Schedule & Comments \\
\hline Best & & & \\
\hline Most Likely & & & \\
\hline Worst & & & \\
\hline
\end{tabular}

$\square$ Very Low $\square$ Low $\square$ Moderate $\square$ High $\square$ Very High

\section{F. Risk Level}
$\square$ Very Low
Low $\square$ Moderate
High
Very High

G. Comments

Drafts of the ROD have been reviewed at DOE-ID and DOE-HQ. Revisions are now underway.

ROD issued on December 13, 2005.

H. Mitigation Plan

\begin{tabular}{|l|l|l|l|}
\hline \multicolumn{1}{|c|}{ Mitigation Actions } & \multicolumn{1}{|c|}{$\begin{array}{c}\text { Scheduled } \\
\text { Implementation }\end{array}$} & Responsibility & $\begin{array}{c}\text { Current } \\
\text { Status }\end{array}$ \\
\hline Schedule shows ROD approval by EM-1 by 12/2/05. & DEC 2, 2005 & Joel Case & Complete \\
\hline $\begin{array}{l}\text { DOE-ID NEPA compliance officer at HQ 11/2-11/10 to } \\
\text { work with GC/EH and EM on finalizing ROD. }\end{array}$ & NOV 10, 2005 & $\begin{array}{l}\text { Jack } \\
\text { Depperschmidt }\end{array}$ & Complete \\
\hline $\begin{array}{l}\text { Project staff at DOE HQ November 14-18 to obtain EH-1/GC } \\
\text { and EM-1 concurrence. A one-week contingency is included to } \\
\text { obtain final approval. }\end{array}$ & DEC 13, 2005 & $\begin{array}{l}\text { Richard } \\
\text { Kimmel }\end{array}$ & Complete \\
\hline
\end{tabular}




\section{RISK ASSESSMENT FORM}

\section{Risk \# IWTU-DOE-005}

Risk Title: External - DOE Operational Readiness Review delays approval of start of operations

\section{A. Statement of Risk}

DOE's Operational Readiness Review may identify project issues that have not been adequately addressed, and may delay start of operations.

\section{B. Assumptions}

Significant facility and system design and operating issues are very likely to be identified and resolved at earlier stages of the project and are unlikely to arise during the Operational Readiness Review (ORR). Therefore additional design, procurement, and construction activities will not be required.

\section{Uncertainties}

ORR reviewers are independent of the IPT and contractor's Project Team and may not agree with resolutions and may identify additional issues not previously evaluated.

\section{Probability}
$\square$ Very Unlikely
Unlikely
Possible
$\bigotimes$ Likely
Very Likely

\section{E. Consequences}

Depending on the issues identified, schedule delay impacts may range from 1-3 months.

\begin{tabular}{|l|l|l|l|}
\hline & Cost & Schedule & Comments \\
\hline Best & $\$ 0$ & 0 Days & \\
\hline Most Likely & $\$ 0$ & 30 days & $\$ 4.6 \mathrm{M} / \mathrm{mo}$ Hotel Load \\
\hline Worst & $\$ 0$ & 90 days & $\$ 3.7 \mathrm{M} / \mathrm{mo}$ Hotel Load \\
\hline
\end{tabular}

$\square$ Very Low $\quad \square$ Low $\square$ Moderate $\square$ High $\square$ Very High

F. Risk Level

$\square$ Very Low $\square$ Low $\quad \square$ Moderate $\square$ High $\square$ Very High

\section{G. Comments}

DOE-ID Operations and Safety organizations will have been engaged in the system design and testing since early project stages.

H. Mitigation Plan

\begin{tabular}{|l|l|l|l|}
\hline \multicolumn{1}{|c|}{ Mitigation Actions } & \multicolumn{1}{|c|}{$\begin{array}{c}\text { Scheduled } \\
\text { Implementation }\end{array}$} & Responsibility & Current Status \\
\hline $\begin{array}{l}\text { Continued engagement of DOE-ID Operations and } \\
\text { Safety organizations in the system design reviews } \\
\text { and testing activities. }\end{array}$ & Ongoing & Joel Case & Ongoing \\
\hline $\begin{array}{l}\text { DOE-ID Operations and Safety organizations to } \\
\text { participate in test activities conducted before the } \\
\text { DOE ORR. }\end{array}$ & $\begin{array}{l}\text { IWMILE 166 } \\
\text { AUG 29, 2009 }\end{array}$ & Joel Case & Planned \\
\hline $\begin{array}{l}\text { Engage the DOE ORR Team prior to the SAT to } \\
\text { enable the team to become familiar with the systems } \\
\text { and operations. }\end{array}$ & $\begin{array}{l}\text { IWTS03180 } \\
\text { JUL 24, 2009 }\end{array}$ & Joel Case & Planned \\
\hline
\end{tabular}




\section{RISK ASSESSMENT FORM}

Risk \# IWTU-DOE-006

Risk Title: External/Internal - DOE delays approval of Critical Decision(s)

\section{A. Statement of Risk}

The Critical Decision dates scheduled for the project may be delayed due to impasse between DOE and the contractor or a change to the long-lead procurement (LLP)/early site work (ESW) approval process in the Project Execution Plan (PEP).

\section{B. Assumptions}

1. DOE will approve Critical Decisions to support the project critical path schedule.

2. DOE will approve Long-Lead Procurements/Early Starts to support the project critical path schedule.

3. PEP revised to include DOE O 413.3A implementation strategy.

\section{Uncertainties}

1. DOE O 413.3A requirements are open for interpretation.

D. Probability

$\square$ Very Unlikely $\square$ Unlikely $\square$ Possible $\square$ Likely $\square$ Very Likely

E. Consequences

Schedule delay impacts may range from 1-3 months.

\begin{tabular}{|l|l|l|l|}
\hline & Cost & Schedule & Comments \\
\hline Best & $\$ 0$ & 0 Days & \\
\hline Most Likely & $\$ 0$ & 30 days & $\$ 4.6 \mathrm{M} / \mathrm{mo}$ Hotel Load \\
\hline Worst & $\$ 0$ & 90 days & $\$ 3.7 \mathrm{M} / \mathrm{mo}$ Hotel Load \\
\hline
\end{tabular}

$\square$ Very Low $\quad$ Low $\square$ Moderate $\square$ High $\square$ Very High

\section{F. Risk Level}

$\square$ Very Low $\square$ Low $\quad \square$ Moderate $\square$ High $\square$ Very High

\section{G. Comments}

The DOE IPT has been actively engaged in the CD Process since early project stages. Weekly calls between the IPT and EM-3 ensure DOE-HQ is apprised of any current project issues or challenges. Meetings with the Office of Performance Assessment have resolved the approach for long leads/early starts required by the Project. CD-2/3B was approved by the Under Secretary of Energy on December 29, 2006. 
H. Mitigation Plan

\begin{tabular}{|c|c|c|c|}
\hline Mitigation Actions & $\begin{array}{c}\text { Scheduled } \\
\text { Implementation }\end{array}$ & Responsibility & Current Status \\
\hline $\begin{array}{l}\text { The Acquisition Strategy will be revised to } \\
\text { include Long Leads and Early Starts as part } \\
\text { of the Project Acquisition Approach. The } \\
\text { Acquisition Strategy will be sent from DOE- } \\
\text { ID to EM-1 for approval by June 30, } 2006 \text {. }\end{array}$ & JUN 26, 2006 & $\begin{array}{l}\text { Integrated } \\
\text { Project Team }\end{array}$ & Complete \\
\hline $\begin{array}{l}\text { EM-1 approved LLP-1 and the Acquisition } \\
\text { Strategy on July 5, } 2006 .\end{array}$ & JUN 26, 2006 & $\begin{array}{l}\text { Integrated } \\
\text { Project Team }\end{array}$ & Complete \\
\hline $\begin{array}{l}\text { Obtain approval of EIR Team for LLP-2, } \\
\text { LLP- } 3 \text { and ESW acquisition approach based } \\
\text { on scheduled dates for package review and } \\
\text { approval. }\end{array}$ & $\begin{array}{l}\text { IWPM0145 } \\
\text { AUG 31, } 2006\end{array}$ & $\begin{array}{l}\text { Integrated } \\
\text { Project Team }\end{array}$ & Complete \\
\hline $\begin{array}{l}\text { Continue discussions with EM-3 to ensure } \\
\text { Acquisition Approach is successful. }\end{array}$ & DEC 29, 2006 & Joel Case & Complete \\
\hline $\begin{array}{l}\text { Resolve EIR Findings and obtain OECM/EM } \\
\text { concurrence for CD-2 approval. }\end{array}$ & $\begin{array}{l}\text { IWPM0165 } \\
\text { OCT } 31,2006\end{array}$ & Joel Case & Complete \\
\hline Obtain LLP-2 package approval. & $\begin{array}{l}\text { IWSW420 } \\
\text { JAN 11, } 2007\end{array}$ & Joel Case & Complete \\
\hline Obtain LLP-3 package approval. & $\begin{array}{l}\text { IWSW520 } \\
\text { APR 24, } 2007\end{array}$ & Joel Case & Complete \\
\hline Obtain ESW Mobilization approval. & JAN 18, 2007 & Joel Case & Complete \\
\hline Obtain ESW-1 approval. & MAR 7, 2007 & Joel Case & Complete \\
\hline Obtain ESW-2 approval. & MAR 7, 2007 & Joel Case & Complete \\
\hline Obtain ESW-3 approval. & MAY 30, 2007 & Joel Case & Complete \\
\hline Obtain ESW-4 approval. & AUG 21, 2007 & Joel Case & On Schedule \\
\hline Obtain CD-3 approval. & AUG 31, 2007 & Joel Case & On Schedule \\
\hline
\end{tabular}




\section{RISK ASSESSMENT FORM}

\section{Risk \# IWTU-DOE-007}

Risk Title: External - DNFSB 2004-2 implementation for active ventilation system

\section{A. Statement of Risk}

Implementation of DNFSB 2004-2 may require a change to the current IWTU design from passive confinement, post-NPH event, to active ventilation.

\section{B. Assumptions}

Discussions with the DNFSB and DOE-HQ have indicated that the IWTU ventilation/confinement design is acceptable.

\section{Uncertainties}

DNFSB 2004-2 implementation plan assessment guidance has not been implemented for IWTU.

\section{Probability}

Very Unlikely $\quad \square$ Unlikely $\square$ Possible $\square$ Likely $\square$ Very Likely

\section{E. Consequences}

Schedule delay of 10 months and cost increase of $\$ 25 \mathrm{M}$ for re-design and implementation to upgrade to active ventilation.

\begin{tabular}{|l|l|l|l|}
\hline & Cost & Schedule & Comments \\
\hline Best & $\$ 0$ & 0 days & \\
\hline Most Likely & $\$ 0$ & 0 days & \\
\hline Worst & $\$ 25 \mathrm{M}$ & 210 days & $\$ 25 \mathrm{M}$ Capital plus $\$ 3.7 \mathrm{M} / \mathrm{mo}$ Hotel Load \\
\hline
\end{tabular}

$\square$ Very Low $\square$ Low $\square$ Moderate $\square$ High $\quad \square$ Very High

\section{F. Risk Level}

Very Low $\square$ Low $\square$ Moderate $\quad \square$ High $\square$ Very High

\section{G. Comments}

DOE HQ and the DNFSB have been involved in project reviews and briefings

\section{H. Mitigation Plan}

\begin{tabular}{|l|l|l|l|}
\hline \multicolumn{1}{|c|}{ Mitigation Actions } & \multicolumn{1}{c|}{$\begin{array}{c}\text { Scheduled } \\
\text { Implementation }\end{array}$} & Responsibility & \multicolumn{1}{c|}{ Current Status } \\
\hline $\begin{array}{l}\text { Continue discussions with DOE-HQ and } \\
\text { involvement of the DNFSB to ensure IWTU } \\
\text { Design is accepted. }\end{array}$ & ONGOING & Joel Case & On Schedule \\
\hline $\begin{array}{l}\text { Execute DNFSB 2004-2 implementation Plan } \\
\text { actions for IWTU. }\end{array}$ & TBD & Joel Case & $\begin{array}{l}\text { After issuance of } \\
\text { updated guidance }\end{array}$ \\
\hline
\end{tabular}




\section{RISK ASSESSMENT FORM}

Risk \# IWTU-DOE-008

Risk Title: External/Internal -10 CFR 851 Implementation for construction subcontractor may delay the critical path schedule

\section{A. Statement of Risk Closed - Risk Mitigated, Constructor will follow the CWI 10 CFR 851 Plan, which was approved in May 2007.}

10 CFR 851 was issued in June 2006 with compliance required complex-wide by May 2007. Risk is that the sub contractor performing the IWTU construction will not have or be able to obtain a compliant program to support the construction schedule.

\section{B. Assumptions}

None

\section{Uncertainties}

None

D. Probability

Very Unlikely $\square$ Unlikely $\square$ Possible $\square$ Likely $\square$ Very Likely

\section{E. Consequences}

\begin{tabular}{|l|l|l|l|}
\hline & Cost & Schedule & Comments \\
\hline Best & & & \\
\hline Most Likely & & & \\
\hline Worst & & & \\
\hline
\end{tabular}

$\square$ Very Low $\square$ Low $\square$ Moderate $\square$ High $\square$ Very High

F. Risk Level

$\square$ Very Low $\square$ Low $\square$ Moderate $\square$ High $\square$ Very High

\section{G. Comments}

\section{H. Mitigation Plan}

\begin{tabular}{|l|l|l|l|}
\hline \multicolumn{1}{|c|}{ Mitigation Actions } & \multicolumn{1}{|c|}{$\begin{array}{c}\text { Scheduled } \\
\text { Implementation }\end{array}$} & Responsibility & \multicolumn{1}{c|}{ Current Status } \\
\hline $\begin{array}{l}\text { Prequalification planning will alert interested } \\
\text { constructors of project requirements, including } \\
\begin{array}{l}10 \text { CFR 851, and allow constructors additional time } \\
\text { to prepare compliant programs. }\end{array}\end{array}$ & IWCO9003 & Mike Cain & Complete \\
\hline
\end{tabular}




\section{RISK ASSESSMENT FORM}

\section{Risk \# IWTU-DOE-009}

Risk Title: External -Post-Seismic Monitoring capability is required

\section{A. Statement of Risk}

Post-Seismic monitoring is not requirement of the ICP Contract and is not included in the design of the IWTU. Post-seismic monitoring was encouraged by the DNFSB in the January 24, 2007, CD-2/3B letter to EM-1.

\section{B. Assumptions}

1. Post-Seismic monitoring is not required per DOE Guide 420.1-1.

2. Incorporation of post-seismic monitoring would be a directed change.

3. Incorporation of post-seismic monitoring can be post CD-3.

4. Incorporation of post-seismic monitoring would require a separate control system that would be seismically qualified.

\section{Uncertainties}

Incorporation of post-seismic monitoring capability into the control system design was encouraged by the DNSFB in the January 24, 2007, letter. DNFSB does not approve design, but recommendations suggested by DNFSB may result in a directed change to incorporate.

\section{Probability}
Very Unlikely
Unlikely
$\bigotimes$ Possible
Likely
Very Likely

\section{E. Consequences}

\begin{tabular}{|l|l|l|l|}
\hline & Cost & Schedule & Comments \\
\hline Best & $\$ 0$ & 0 days & \\
\hline Most Likely & $\$ 0$ & 0 days & \\
\hline Worst & $\$ 3 \mathrm{M}$ & 120 days & $\$ 3 \mathrm{M}$ capital cost plus $\$ 3.7 \mathrm{M} /$ mon Hotel Load (30+ days) \\
\hline
\end{tabular}

Very Low $\quad \square$ Low $\square$ Moderate $\square$ High $\square$ Very High

\section{F. Risk Level}
Very Low
Low
$\bigotimes$ Moderate
High
Very High

\section{G. Comments}

\section{H. Mitigation Plan}

\begin{tabular}{|l|l|l|l|}
\hline \multicolumn{1}{|c|}{ Mitigation Actions } & $\begin{array}{c}\text { Scheduled } \\
\text { Implementation }\end{array}$ & Responsibility & \multicolumn{1}{|c|}{ Current Status } \\
\hline $\begin{array}{l}\text { Continue discussions with DOE-HQ and } \\
\text { involvement of the DNFSB to ensure IWTU design } \\
\text { is accepted. }\end{array}$ & $\begin{array}{l}\text { September 2007, } \\
\text { concurrent with } \\
\text { CD-3 approval }\end{array}$ & Joel Case & On schedule \\
\hline
\end{tabular}




\section{RISK ASSESSMENT FORM}

\section{Risk \# IWTU-DOE-010}

Risk Title: External/Internal - Full Application of ISA 84.00.01 is required for the IWTU control System

\section{A. Statement of Risk}

ISA 84.00.01 is a risk based standard that requires additional evaluations based on consequences. During the hazard and risk assessment phase, the process risk is compared to the tolerable risk to determine the amount of risk reduction that must be provided by various safety functions. The safety functions are then allocated to different systems, such as the Basic Process Control System (BPCS), Safety Instrumented System (SIS), external fire and gas systems, etc. When a safety function is allocated to the SIS, it is called a Safety Instrumented Function (SIF). The allocation process also includes assigning a Safety Integrity Level (SIL) to the SIF, which corresponds to the amount of risk reduction that was determined to be necessary in the hazard and risk analysis. The current design of the IWTU Control System complies with ISA-84.00.01 and full application is not requirement of the ICP Contract and is not included in the design of the IWTU. However, full application has been questioned by the DNFSB.

\section{B. Assumptions}

1. Full application of ISA-84.00.01 does not apply to the design of the IWTU control system based on Hazardous Chemical Inventories.

2. Full application of ISA-84.00.01 does not apply to the design of the IWTU control system as the Radiological consequences are relatively low.

3. Incorporation can be post CD-3.

4. Incorporation of would be a directed change.

\section{Uncertainties}

Full application of ISA 84.00.01 has been questioned by the DNSFB staff. DNFSB does not approve design, but recommendations suggested by DNFSB may result in a directed change to incorporate.

\section{Probability}

$\square$ Very Unlikely $\square$ Unlikely $\quad$ Possible $\square$ Likely $\square$ Very Likely

\section{E. Consequences}

\begin{tabular}{|l|l|l|l|}
\hline & Cost & Schedule & Comments \\
\hline Best & $\$ 0$ & 0 days & \\
\hline Most Likely & $\$ 0$ & 0 days & \\
\hline Worst & $\$ 3 \mathrm{M}$ & 180 days & $\$ 3 \mathrm{M}$ capital cost plus $\$ 3.7 \mathrm{M} /$ mon Hotel Load (30+ days) \\
\hline
\end{tabular}

$\square$ Very Low $\square$ Low $\square$ Moderate $\square$ High $\square$ Very High

\section{F. Risk Level}

Very Low $\square$ Low $\square$ Moderate $\square$ High $\square$ Very High

\section{G. Comments}




\section{H. Mitigation Plan}

\begin{tabular}{|l|l|l|l|}
\hline \multicolumn{1}{|c|}{ Mitigation Actions } & \multicolumn{1}{|c|}{$\begin{array}{c}\text { Scheduled } \\
\text { Implementation }\end{array}$} & Responsibility & \multicolumn{1}{c|}{ Current Status } \\
\hline $\begin{array}{l}\text { Continue discussions with DOE-HQ and } \\
\text { involvement of the DNFSB to ensure IWTU } \\
\text { control system design is accepted. }\end{array}$ & $\begin{array}{l}\text { August 2007, } \\
\text { concurrent with } \\
\text { CD-3 approval }\end{array}$ & Joel Case & On schedule \\
\hline
\end{tabular}


Appendix C

Monte Carlo Analysis Results 


$$
\text { C-2 }
$$




\section{Appendix C}

\section{Monte Carlo Analysis Results}

\section{Forecast: DOE Risk \$}

Summary:

Entire range is from 3,311 to 89,325

Base case is 116,100

After 5,000 trials, the std. error of the mean is 185

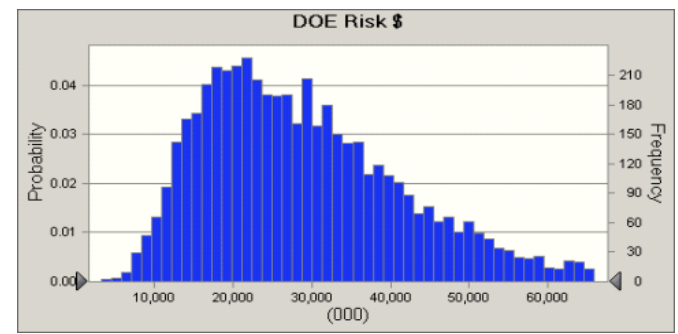

Percentiles:

$0 \%$

$10 \%$

$20 \%$

$30 \%$

$40 \%$

$50 \%$

$60 \%$

$70 \%$

$80 \%$

$90 \%$

$100 \%$
Forecast values

3,311

14,407

17,730

20,591

23,639

26,956

30,414

34,478

39,593

47,544

89,325 


\section{Forecast: DOE Risk Days}

\section{Summary:}

Entire range is from 27 to 447

Base case is 690

After 5,000 trials, the std. error of the mean is 1

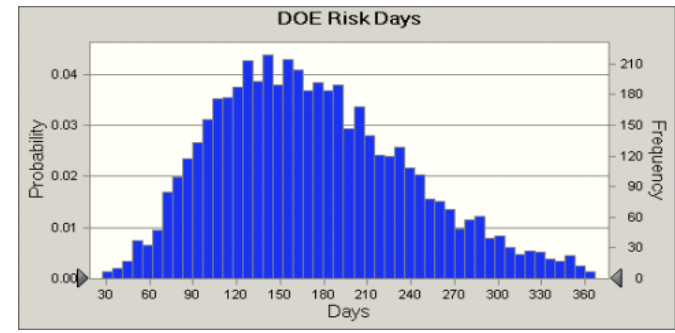

$\begin{array}{cr}\text { Percentiles: } & \text { Forecast values } \\ 0 \% & 27 \\ 10 \% & 92 \\ 20 \% & 114 \\ 30 \% & 132 \\ 40 \% & 149 \\ 50 \% & 165 \\ 60 \% & 184 \\ 70 \% & 205 \\ 80 \% & 231 \\ 90 \% & 268 \\ 100 \% & 447\end{array}$

End of Forecasts

Assumption: DOE-005 DOE Operational Readiness Review delays approval of start of operations (=B2)

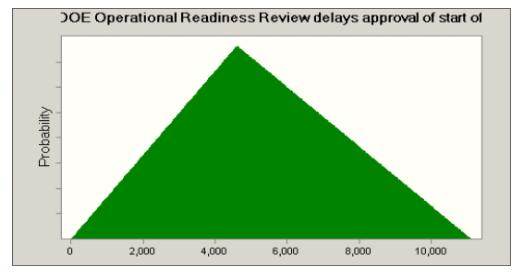
Percentiles:
Assumption values
2,256
Distribution
$10 \%$
8,457
2,260
8,414 
Assumption: DOE-005 DOE Operational Readiness Review delays approval of start of operations (K2) (=B2)

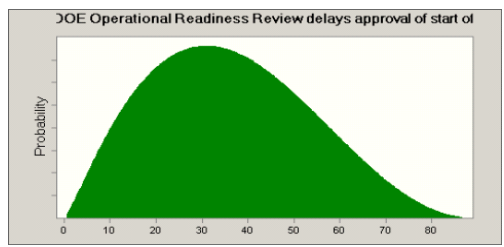

$\begin{array}{crr}\text { Percentiles: } & \text { Assumption values } & \text { Distribution } \\ 10 \% & 13 & 14 \\ 90 \% & 60 & 60\end{array}$

Assumption: DOE-006 DOE delays approval of Critical Decision(s) (=B3)

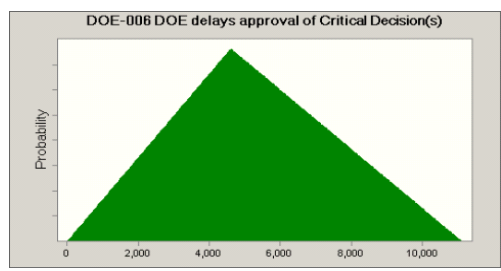
Percentiles:
Assumption values
Distribution
$10 \%$
2,279
2,260
$90 \%$
8,373
8,414

Assumption: DOE-006 DOE delays approval of Critical Decision(s) (K3) (=B3)

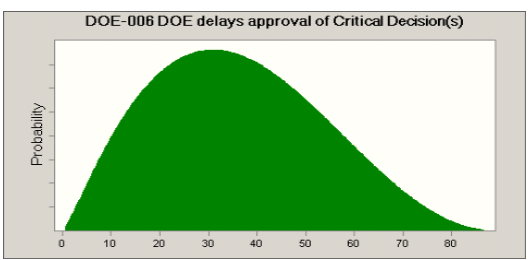

$\begin{array}{crr}\text { Percentiles: } & \text { Assumption values } & \text { Distribution } \\ 10 \% & 13 & 14 \\ 90 \% & 60 & 60\end{array}$


Assumption: DOE-007 DNFSB 2004-2 implementation for active ventilation system (=B4)

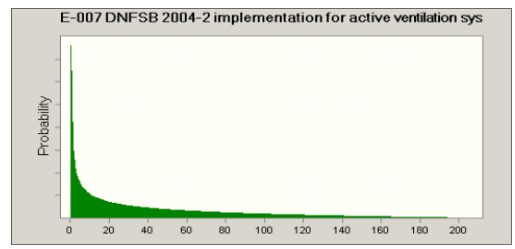

$\begin{array}{crr}\text { Percentiles: } & \text { Assumption values } & \text { Distribution } \\ 10 \% & 1 & 1 \\ 90 \% & 109 & 112\end{array}$

Assumption: DOE-007 DNFSB 2004-2 implementation for active ventilation system (H4) (=B4)

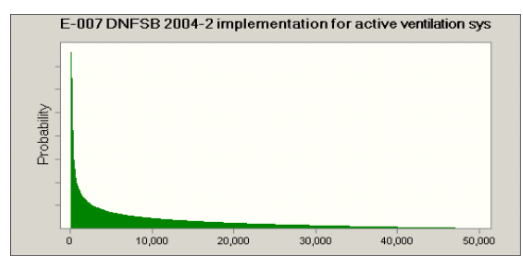

$\begin{array}{crr}\text { Percentiles: } & \text { Assumption values } & \text { Distribution } \\ 10 \% & 229 & 227 \\ 90 \% & 27,209 & 27,073\end{array}$

Assumption: DOE-009 Post Seismic Monitoring capability is required (=B5)

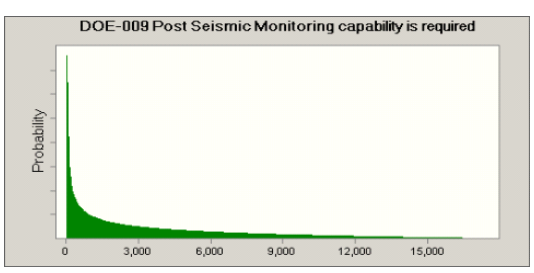
Percentiles:
Assumption values
Distribution
$10 \%$
79
79
$90 \%$
9,239
9,467 
Assumption: DOE-009 Post Seismic Monitoring capability is required (K5) (=B5)

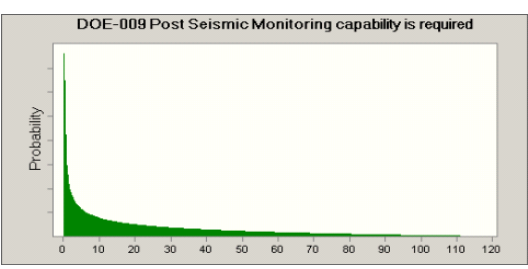

$\begin{array}{crr}\text { Percentiles: } & \text { Assumption values } & \text { Distribution } \\ 10 \% & 1 & 1 \\ 90 \% & 63 & 64\end{array}$

Assumption: DOE-010 Full Application of ISA 84.00.01 is required for the IWTU control System (=B6)

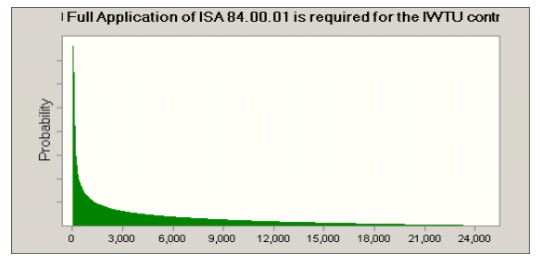
Percentiles:
Assumption values
Distribution
$10 \%$
116
112
$90 \%$
13,470
13,403

Assumption: DOE-010 Full Application of ISA 84.00.01 is required for the IWTU control System (K6) (=B6)

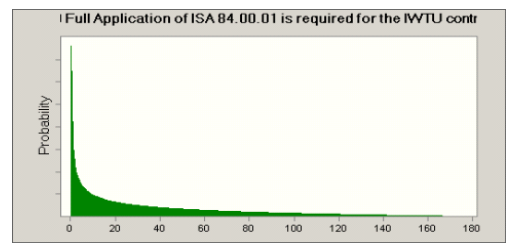

$\begin{array}{crr}\text { Percentiles: } & \text { Assumption values } & \text { Distribution } \\ 10 \% & 1 & 1 \\ 90 \% & 98 & 96\end{array}$

End of Assumptions 
Appendix D

Risk Register 
D-2 


\section{Appendix D}

\section{Risk Register}

\begin{tabular}{|c|c|c|c|c|c|c|}
\hline Number & Scenario & Risks Identified & Category of Risk & Sub-Category & Assumptions & Uncertainties \\
\hline DOE-001 & $\begin{array}{l}\text { DOE adds requirements beyond those } \\
\text { required by Code of Record. Closed - } \\
\text { Risk Accepted. EM-1 approved Path } \\
\text { Forward Action Memorandum on } \\
\text { February 27, 2006. Memorandum } \\
\text { confirmed Facility Performance } \\
\text { Categorization. }\end{array}$ & $\begin{array}{l}\text { - Critical Path } \\
\text { Schedule } \\
\text { slippage } \\
\text { - Cost increase to } \\
\text { redesign }\end{array}$ & External & Requirements & $\begin{array}{l}\text { Although DOE reviews during } \\
\text { development of the design occur and } \\
\text { have so far proven to be effective, } \\
\text { additional requirements may arise later } \\
\text { in the life of the project. }\end{array}$ & None \\
\hline DOE-002 & $\begin{array}{l}\text { SBW is determined to be HLW. Risk } \\
\text { removed from the Monte Carlo } \\
\text { Analysis. In the event the SBW is } \\
\text { determined to be HLW the project } \\
\text { would be re-baselined. }\end{array}$ & $\begin{array}{l}\text { - Critical Path } \\
\text { Schedule } \\
\text { slippage } \\
\text { - } \begin{array}{l}\text { Cost increase to } \\
\text { redesign }\end{array}\end{array}$ & External & $\begin{array}{l}\text { - Requirements } \\
\text { - Political }\end{array}$ & $\begin{array}{l}\text { SBW will be determined to be TRU } \\
\text { Waste and will be disposed at WIPP. }\end{array}$ & $\begin{array}{l}\text { The outcome of the DOE-HQ } \\
\text { Waste Determination }\end{array}$ \\
\hline DOE-003 & $\begin{array}{l}\text { WIPP RCRA Class } 3 \text { Permit modification } \\
\text { to allow disposal of SBW Treated } \\
\text { Product is not obtained. Future } \\
\text { Consideration - no impact to capital } \\
\text { project. }\end{array}$ & $\begin{array}{l}\text { Cost increase post } \\
\text { Capital Project }\end{array}$ & External & $\begin{array}{l}\text { - Requirements } \\
\text { - Political }\end{array}$ & $\begin{array}{l}\text { - This risk is outside the Capital } \\
\text { Project therefore there is no risk to } \\
\text { the Capital Project. } \\
\text { - The Project needs to continue to } \\
\text { work to obtain the permit in time to } \\
\text { complete the transfer of the waste } \\
\text { product to WIPP by } \\
\text { September 2012. }\end{array}$ & $\begin{array}{l}\text { Political and Regulatory } \\
\text { environments are uncertain at this } \\
\text { time. }\end{array}$ \\
\hline DOE-004 & $\begin{array}{l}\text { EIS Record of Decision not achieved by } \\
\text { December 2005. Closed - Risk } \\
\text { Mitigated. Record of Decision issued in } \\
\text { December 2005. }\end{array}$ & $\begin{array}{l}\text { Critical Path } \\
\text { Schedule slippage }\end{array}$ & External & $\begin{array}{l}\text { - Requirements } \\
\text { - Stakeholders }\end{array}$ & None & None \\
\hline DOE-005 & $\begin{array}{l}\text { DOE Operational Readiness Review } \\
\text { delays approval of start of operations. }\end{array}$ & $\begin{array}{l}\text { Critical Path } \\
\text { Schedule slippage }\end{array}$ & External & $\begin{array}{l}\text { - Stakeholders } \\
\text { - Requirements }\end{array}$ & $\begin{array}{l}\text { Significant facility and system design } \\
\text { and operating issues are very likely to } \\
\text { be identified and resolved at earlier } \\
\text { stages of the project and are unlikely to } \\
\text { arise during the Operational Readiness } \\
\text { Review. Therefore additional design, } \\
\text { procurement, and construction } \\
\text { activities will not be required. }\end{array}$ & $\begin{array}{l}\text { ORR reviewers are independent of } \\
\text { the IPT and Project Team and may } \\
\text { not agree with resolutions and may } \\
\text { identify additional issues not } \\
\text { previously evaluated. }\end{array}$ \\
\hline
\end{tabular}




\begin{tabular}{|c|c|c|c|c|c|c|}
\hline Number & Scenario & Risks Identified & Category of Risk & Sub-Category & Assumptions & Uncertainties \\
\hline DOE-006 & $\begin{array}{l}\text { DOE delays approval of Critical } \\
\text { Decision(s). }\end{array}$ & $\begin{array}{l}\text { Critical Path } \\
\text { Schedule slippage }\end{array}$ & - External & $\begin{array}{l}\text { - Requirements } \\
\text { - Organizational }\end{array}$ & $\begin{array}{l}\text { DOE will approve Critical } \\
\text { Decisions to support the project } \\
\text { critical path schedule. } \\
\text { - DOE will approve Long-Lead } \\
\text { Procurements/Early Starts to } \\
\text { support the project critical path } \\
\text { schedule. } \\
\text { - PEP revised to include } \\
\text { DOE O 413.3A Implementation } \\
\text { Strategy. }\end{array}$ & $\begin{array}{l}\text { - DOE O 413.3A requirements } \\
\text { are open for interpretation. }\end{array}$ \\
\hline DOE-007 & $\begin{array}{l}\text { DNFSB 2004-2 implementation for } \\
\text { active ventilation system. }\end{array}$ & $\begin{array}{l}\text { - Critical Path } \\
\text { Schedule } \\
\text { slippage } \\
\text { - Cost increase to } \\
\text { redesign }\end{array}$ & External & $\begin{array}{l}\text { - Stakeholders } \\
\text { - Requirements }\end{array}$ & $\begin{array}{l}\text { Discussions with the DNFSB and DOE } \\
\text { HQ have indicated that the IWTU } \\
\text { ventilation/confinement design is } \\
\text { acceptable. }\end{array}$ & $\begin{array}{l}\text { - DNFSB 2004-2 implementation } \\
\text { plan assessment guidance has } \\
\text { not been implemented for } \\
\text { IWTU. } \\
\text { - Report has been submitted for } \\
\text { IWTU but not sure if it will be } \\
\text { accepted or who will accept. } \\
\end{array}$ \\
\hline DOE-008 & $\begin{array}{l}10 \text { CFR } 851 \text { Implementation for } \\
\text { construction subcontractor may delay the } \\
\text { critical path schedule. Closed - Risk } \\
\text { Mitigated. Constructor will follow the } \\
\text { CWI } 10 \text { CFR } 851 \text { Plan, which was } \\
\text { approved by DOE in May 2007. }\end{array}$ & $\begin{array}{l}\text { Critical Path } \\
\text { Schedule slippage }\end{array}$ & $\begin{array}{l}\text { - External } \\
\text { - Internal }\end{array}$ & Requirements & None & None \\
\hline DOE-009 & $\begin{array}{l}\text { Post-Seismic Monitoring capability is } \\
\text { required. }\end{array}$ & $\begin{array}{l}\text { - Critical Path } \\
\text { Schedule } \\
\text { slippage } \\
\text { - Cost Increase } \\
\text { due to redesign }\end{array}$ & External & $\begin{array}{l}\text { - Stakeholders } \\
\text { - Requirements }\end{array}$ & $\begin{array}{l}\text { Post-seismic monitoring is not } \\
\text { required per DOE Guide } 420.1-1 . \\
\text { - Incorporation of post-seismic } \\
\text { monitoring would be a directed } \\
\text { change. } \\
\text { - Incorporation of post-seismic } \\
\text { monitoring can be post CD-3. } \\
\text { - Incorporation of post-seismic } \\
\text { monitoring would require a separate } \\
\text { control system that would be } \\
\text { seismically qualified. }\end{array}$ & $\begin{array}{l}\text { Incorporation of Post-Seismic } \\
\text { Monitoring capability into the } \\
\text { control system design was } \\
\text { encouraged by the DNSFB in } \\
\text { the January } 24,2007 \text {, letter. } \\
\text { DNFSB does not approve } \\
\text { design, but recommendations } \\
\text { suggested by DNFSB may } \\
\text { result in a directed change to } \\
\text { incorporate. }\end{array}$ \\
\hline
\end{tabular}




\begin{tabular}{|c|c|c|c|c|c|c|}
\hline Number & Scenario & Risks Identified & Category of Risk & Sub-Category & Assumptions & Uncertainties \\
\hline DOE-010 & $\begin{array}{l}\text { DNFSB does not concur with the Design } \\
\text { of IWTU Control System. }\end{array}$ & $\begin{array}{l}\text { - Critical Path } \\
\text { Schedule } \\
\text { slippage } \\
\text { - Cost Increase } \\
\text { due to redesign }\end{array}$ & \begin{tabular}{ll|} 
- & External \\
- Internal
\end{tabular} & $\begin{array}{l}\text { - Stakeholders } \\
\text { - Requirements }\end{array}$ & $\begin{array}{l}\text { - Full application of ISA-84.00.01 } \\
\text { does not apply to the design of the } \\
\text { IWTU control system based on } \\
\text { Hazardous Chemical Inventories. } \\
\text { - Full application of ISA- } 84.00 .01 \\
\text { does not apply to the design of the } \\
\text { IWTU control system as the } \\
\text { radiological consequences are } \\
\text { relatively low. } \\
\text { - Incorporation can be post CD-3. } \\
\text { - Incorporation would be a directed } \\
\text { change. }\end{array}$ & $\begin{array}{l}\text { - Full application of } \\
\text { ISA-84.00.01 has been } \\
\text { questioned by the DNSFB staff } \\
\text { DNFSB does not approve } \\
\text { design, but recommendations } \\
\text { suggested by DNFSB may } \\
\text { result in a directed change to } \\
\text { incorporate. }\end{array}$ \\
\hline IWTU-001 & $\begin{array}{l}\text { Deposits form on the waste feed nozzle to } \\
\text { the DM reformer and the nozzle clogs } \\
\text { interrupting operations. }\end{array}$ & $\begin{array}{l}\text { - Critical Path } \\
\text { Schedule } \\
\text { slippage } \\
\text { - Cost increase to } \\
\text { redesign }\end{array}$ & Technical & $\begin{array}{l}\text { - Simulation } \\
\text { - Design/Eng }\end{array}$ & $\begin{array}{l}\text { - Mock-up test program demonstrates } \\
\text { acceptable un-cooled feed nozzle } \\
\text { design. } \\
\text { - Nozzle clearing methods, (flush } \\
\text { with water or acid) demonstrated at } \\
\text { Hazen, are effective. } \\
\text { - Un-cooled nozzles in IWTU } \\
\text { baseline will be effective based on } \\
\text { experience using un-cooled nozzles } \\
\text { in the New Waste Calcining } \\
\text { Facility. } \\
\end{array}$ & $\begin{array}{l}\text { SAT identifies problems that were } \\
\text { not identified during Mock-up } \\
\text { Testing. }\end{array}$ \\
\hline IWTU-002 & $\begin{array}{l}\text { Scale-up of the steam reforming process } \\
\text { to treat Sodium Bearing Wastes (SBW) } \\
\text { could result in lower throughputs than } \\
\text { planned in the design. Closed - Risk } \\
\text { Mitigated by Test Program. }\end{array}$ & $\begin{array}{l}\text { Critical Path } \\
\text { Schedule slippage }\end{array}$ & Technical & $\begin{array}{l}\text { - Simulation } \\
\text { - Design/Eng }\end{array}$ & None & None \\
\hline IWTU-003 & $\begin{array}{l}\text { The waste form created in the steam } \\
\text { reforming process does not comply with } \\
\text { WIPP Waste Acceptance Criteria } \\
\text { requirements. Risk Closed - Final WIPP } \\
\text { WAC has been issued. }\end{array}$ & $\begin{array}{l}\text { Cost increase to } \\
\text { redesign }\end{array}$ & $\begin{array}{l}\text { - Technical } \\
\text { - External }\end{array}$ & $\begin{array}{l}\text { - Operational } \\
\text { - Requirements } \\
\text { - Stakeholders }\end{array}$ & None & None \\
\hline IWTU-004 & $\begin{array}{l}\text { IWTU Environmental Permits approval } \\
\text { cannot be obtained in a timely manner. } \\
\text { Risk Closed - IWTU Permits issued by } \\
\text { Regulatory Agencies May 2007. }\end{array}$ & $\begin{array}{l}\text { Critical Path } \\
\text { Schedule slippage }\end{array}$ & $\begin{array}{l}\text { - External } \\
\text { - Program }\end{array}$ & $\begin{array}{l}\text { - Stakeholders } \\
\text { - Requirements }\end{array}$ & None & None \\
\hline
\end{tabular}




\begin{tabular}{|c|c|c|c|c|c|c|}
\hline Number & Scenario & Risks Identified & Category of Risk & Sub-Category & Assumptions & Uncertainties \\
\hline IWTU-005 & $\begin{array}{l}\text { Full scale SBW off-gas emissions are not } \\
\text { compliant with MACT requirements or } \\
\text { do not meet environmental criteria during } \\
\text { the SAT. Closed - Risk Accepted. }\end{array}$ & $\begin{array}{l}\text { - Critical Path } \\
\text { Schedule } \\
\text { slippage } \\
\text { - Cost increase to } \\
\text { redesign }\end{array}$ & $\begin{array}{l}\text { - Technical } \\
\text { - External }\end{array}$ & $\begin{array}{l}\text { - Simulation } \\
\text { - Requirements } \\
\text { - Operational }\end{array}$ & $\begin{array}{l}\text { Design modifications are not } \\
\text { required to ensure that emissions } \\
\text { meet MACT requirements. } \\
\text { - Additional risk modeling does not } \\
\text { need to be performed. } \\
\text { - Prior testing has demonstrated that } \\
\text { the off-gas system design produces } \\
\text { MACT compliant emissions. Hazen } \\
\text { results also indicate MACT } \\
\text { compliant emissions. }\end{array}$ & $\begin{array}{l}\text { Full-Scale SAT demonstrates } \\
\text { unanticipated results and design } \\
\text { modifications or procedural } \\
\text { modifications are required. }\end{array}$ \\
\hline IWTU-006 & $\begin{array}{l}\text { DEQ does not issue Temporary } \\
\text { Authorization for early construction. } \\
\text { Closed - Risk Mitigated. TA approved } \\
\text { effective March 1, 2007. }\end{array}$ & $\begin{array}{l}\text { Critical Path } \\
\text { Schedule slippage }\end{array}$ & $\begin{array}{l}\text { - External } \\
\text { - Internal }\end{array}$ & $\begin{array}{l}\text { - Stakeholders } \\
\text { - Requirements } \\
\text { - Organizational } \\
\end{array}$ & None & None \\
\hline IWTU-007 & $\begin{array}{l}\text { Long Lead Procurement is denied. } \\
\text { Closed - Risk Mitigated by issuance of } \\
\text { CD-2/3B on December 29, } 2006\end{array}$ & $\begin{array}{l}\text { Critical Path } \\
\text { Schedule slippage }\end{array}$ & $\begin{array}{l}\text { - External } \\
\text { - Internal }\end{array}$ & $\begin{array}{l}\text { - Resources } \\
\text { - Requirements } \\
\text { - Political } \\
\end{array}$ & None & None \\
\hline IWTU-008 & $\begin{array}{l}\text { Site-specific geological investigations } \\
\text { identify conditions that affect seismic } \\
\text { design basis. Closed - Risk Mitigated by } \\
\text { issuance of Geotechnical Report in } \\
\text { June } 2007 \text { and briefing EM-HQ. }\end{array}$ & $\begin{array}{l}\text { Critical Path } \\
\text { Schedule slippage }\end{array}$ & $\begin{array}{l}\text { - External } \\
\text { - Technical }\end{array}$ & $\begin{array}{l}\text { - Design/Eng } \\
\text { - Requirements } \\
\text { - Stakeholders } \\
\text { - Systems } \\
\end{array}$ & None & None \\
\hline IWTU-009 & $\begin{array}{l}\text { Particle size control problems. Closed - } \\
\text { Risk Mitigated by Test Program. }\end{array}$ & $\begin{array}{l}\text { Cost increase to } \\
\text { redesign }\end{array}$ & Technical & $\begin{array}{l}\text { Simulation } \\
\text { Design/Eng }\end{array}$ & None & None \\
\hline IWTU-010 & $\begin{array}{l}\text { Product removal equipment fails to } \\
\text { function, and requires shutdown and } \\
\text { manual clean out. }\end{array}$ & $\begin{array}{l}\text { - Critical Path } \\
\text { Schedule } \\
\text { slippage } \\
\text { - Cost increase to } \\
\text { redesign }\end{array}$ & Technical & $\begin{array}{l}\text { - Simulation } \\
\text { - Function } \\
\text { - Base Technology }\end{array}$ & $\begin{array}{l}\text { - Mockup testing conducted by fill } \\
\text { station vendor ensures canister } \\
\text { filling capability and reliability. } \\
\text { - Mockup testing conducted by vessel } \\
\text { fabricator ensures product solids } \\
\text { handling capability from DMR } \\
\text { through canister filling. } \\
\text { - Product flow properties evaluated } \\
\text { by vendor to confirm design input. } \\
\text { - Calcine product successfully } \\
\text { transferred to Bin Sets at INTEC } \\
\text { over many years. }\end{array}$ & $\begin{array}{l}\text { Transfer of steam reformed } \\
\text { product solids to the RH-72B } \\
\text { canister has not been demonstrated } \\
\text { with either actual or simulant } \\
\text { waste product solids. }\end{array}$ \\
\hline
\end{tabular}




\begin{tabular}{|c|c|c|c|c|c|c|}
\hline Number & Scenario & Risks Identified & Category of Risk & Sub-Category & Assumptions & Uncertainties \\
\hline IWTU-011 & $\begin{array}{l}\text { Actual waste received at IWTU is } \\
\text { significantly different from contracted } \\
\text { waste characterization data. Future } \\
\text { Consideration - No impact to capital } \\
\text { project }\end{array}$ & $\begin{array}{l}\text { Operations Critical } \\
\text { Path Schedule } \\
\text { slippage }\end{array}$ & Technical & $\begin{array}{l}\text { - Operational } \\
\text { - Systems }\end{array}$ & $\begin{array}{l}\text { - This risk is outside the Capital } \\
\text { Project therefore there is no risk to } \\
\text { the Capital Project. } \\
\text { - Significant sample data is available, } \\
\text { and tank homogeneity is anticipated. }\end{array}$ & $\begin{array}{l}\text { Solids data is not as well known } \\
\text { and could require blending in } \\
\text { NWCF to control product and feed } \\
\text { batch limits. Possibly impacts } \\
\text { operating schedule. }\end{array}$ \\
\hline IWTU-012 & $\begin{array}{l}\text { Waste/Product Sampling Requirements. } \\
\text { Future Consideration - No impact to } \\
\text { capital project }\end{array}$ & $\begin{array}{l}\text { - Operations } \\
\text { Critical Path } \\
\text { Schedule } \\
\text { slippage } \\
\text { - Lifecycle } \\
\text { (Operations) } \\
\text { Cost Increase } \\
\end{array}$ & $\begin{array}{l}\text { - Technical } \\
\text { - Internal }\end{array}$ & $\begin{array}{l}\text { - Operational } \\
\text { - Integration }\end{array}$ & $\begin{array}{l}\text { - This risk is outside the Capital } \\
\text { Project therefore there is no risk to } \\
\text { the Capital Project. } \\
\text { - Significant remote laboratory } \\
\text { capabilities exist at INTEC } \\
\text { therefore insufficient analytical } \\
\text { capabilities is very unlikely. }\end{array}$ & $\begin{array}{l}\text { If sampling requirements to meet } \\
\text { WIPP acceptance criteria are } \\
\text { excessive (per canister-for } \\
\text { example) additional analytical } \\
\text { capacity may be required and is } \\
\text { likely to be costly. }\end{array}$ \\
\hline IWTU-013 & $\begin{array}{l}\text { Changes in MACT requirements. Closed } \\
\text { - Risk Occurred. }\end{array}$ & $\begin{array}{l}\text { - Critical Path } \\
\text { Schedule } \\
\text { slippage } \\
\text { - Cost increase to } \\
\text { redesign }\end{array}$ & $\begin{array}{l}\text { - External } \\
\text { - Technical }\end{array}$ & $\begin{array}{l}\text { - Requirements } \\
\text { - Design/Eng }\end{array}$ & None & None \\
\hline IWTU-014 & $\begin{array}{l}100 \text {-year flood plain. Closed - } \\
\text { Mutigation Stratgey reduced residual } \\
\text { Risk to Zero. }\end{array}$ & $\begin{array}{l}\text { - Critical Path } \\
\text { Schedule } \\
\text { slippage } \\
\text { - Cost increase to } \\
\text { redesign } \\
\end{array}$ & - External & $\begin{array}{l}\text { - Requirements } \\
\text { - Stakeholders } \\
\text { - Political }\end{array}$ & None & None \\
\hline IWTU-015 & $\begin{array}{l}\text { SR product density not achieved. Future } \\
\text { Consideration - No impact to capital } \\
\text { project. }\end{array}$ & $\begin{array}{l}\text { - Operations } \\
\text { Critical Path } \\
\text { Schedule } \\
\text { slippage } \\
\text { - Lifecycle } \\
\text { (Operations) } \\
\text { Cost Increase } \\
\end{array}$ & Technical & $\begin{array}{l}\text { - Operational } \\
\text { - Design/Eng } \\
\text { - } \text { Systems }\end{array}$ & $\begin{array}{l}\text { - This risk is outside the Capital } \\
\text { Project therefore there is no risk to } \\
\text { the Capital Project. } \\
\text { - Shipping will occur concurrently } \\
\text { with production and therefore } \\
\text { additional storage space will not be } \\
\text { required. }\end{array}$ & $\begin{array}{l}\text { WIPP permit and shipping } \\
\text { schedules (GFSI) }\end{array}$ \\
\hline
\end{tabular}




\begin{tabular}{|c|c|c|c|c|c|c|}
\hline Number & Scenario & Risks Identified & Category of Risk & Sub-Category & Assumptions & Uncertainties \\
\hline IWTU-016 & Availability $(70 \%)$ may not be achieved. & $\begin{array}{l}\text { Critical Path } \\
\text { Schedule slippage }\end{array}$ & Technical & $\begin{array}{l}\text { - Operational } \\
\text { - Simulation } \\
\text { - Function }\end{array}$ & $\begin{array}{l}\text { - Normal startup problems for a new } \\
\text { process may have a significant } \\
\text { impact on overall availability and } \\
\text { are adequately accounted for in the } \\
\text { start-up schedule. } \\
\text { - Hazen testing has demonstrated the } \\
\text { ability to operate at higher than the } \\
\text { nominal } 2.5 \text { gpm (scaled) } \\
\text { throughput which will compensate } \\
\text { for some maintenance delays. } \\
\text { - Selected custom components will be } \\
\text { successfully tested as part of the } \\
\text { mockup test program. }\end{array}$ & $\begin{array}{l}\text { First of a kind facility may have } \\
\text { unanticipated startup problems, } \\
\text { some which could impact Site } \\
\text { Acceptance Testing. }\end{array}$ \\
\hline IWTU-017 & $\begin{array}{l}\text { Construction/Fabrication Material } \\
\text { Availability. }\end{array}$ & $\begin{array}{l}\text { - Critical Path } \\
\text { Schedule } \\
\text { slippage } \\
\text { - Cost increase to } \\
\text { Project }\end{array}$ & $\begin{array}{l}\text { - Program } \\
\text { - External }\end{array}$ & $\begin{array}{l}\text { - Sequencing } \\
\text { - } \text { Cost } \\
\text { - Market Threat } \\
\text { - Threat }\end{array}$ & $\begin{array}{l}\text { - Construction estimate includes } \\
\text { realistic assumptions regarding } \\
\text { escalation of material. } \\
\text { - Construction estimate includes } \\
\text { realistic assumptions regarding } \\
\text { availability to meet the project } \\
\text { schedule. } \\
\text { - Vendors are capable and willing to } \\
\text { produce materials capable of } \\
\text { meeting project quality } \\
\text { requirements. }\end{array}$ & $\begin{array}{l}\text { - Weather, political turmoil, and } \\
\text { wars, affect material availability } \\
\text { and costs, and may undermine } \\
\text { the assumptions. } \\
\text { - Vendors may not want to bid or } \\
\text { cannot produce materials } \\
\text { capable of meeting project } \\
\text { quality requirements. }\end{array}$ \\
\hline IWTU-018 & $\begin{array}{l}\text { DMR-CRR operation is difficult to } \\
\text { balance and control. Closed - Risk } \\
\text { Mitigated by Test Program. }\end{array}$ & $\begin{array}{l}\text { - Critical Path } \\
\text { Schedule } \\
\text { slippage } \\
\text { - Cost increase to } \\
\text { redesign } \\
\end{array}$ & Technical & $\begin{array}{l}\text { - Operational } \\
\text { - Design/Eng } \\
\text { - Systems }\end{array}$ & None & None \\
\hline IWTU-019 & $\begin{array}{l}\text { Early Site Work approval is denied. } \\
\text { Closed - Risk IWTU-007 Revised to } \\
\text { include all Long-Lead Procurements } \\
\text { and early starts proposed by the } \\
\text { project. }\end{array}$ & $\begin{array}{l}\text { Critical Path } \\
\text { Schedule slippage }\end{array}$ & External & $\begin{array}{l}\text { - Resources } \\
\text { - Requirements } \\
\text { - Political }\end{array}$ & None & None \\
\hline
\end{tabular}




\begin{tabular}{|c|c|c|c|c|c|c|}
\hline Number & Scenario & Risks Identified & Category of Risk & Sub-Category & Assumptions & Uncertainties \\
\hline IWTU-020 & $\begin{array}{l}\text { Canister Filling and Closure System } \\
\text { Performance not acceptable. }\end{array}$ & $\begin{array}{l}\text { - Operations } \\
\text { Critical Path } \\
\text { Schedule } \\
\text { slippage } \\
\text { - Lifecycle } \\
\text { (Operations) } \\
\text { Cost Increase } \\
\text { - Capital Cost } \\
\text { Increase } \\
\text { - Critical Path } \\
\text { Schedule } \\
\text { slippage } \\
\end{array}$ & Technical & $\begin{array}{l}\text { - Operational } \\
\text { - Design/Eng } \\
\text { - Systems }\end{array}$ & $\begin{array}{l}\text { - Actual award of PO to Canister } \\
\text { Filling and Closure System Vendor } \\
\text { left a portion of the risk with the } \\
\text { project. } \\
\text { - Early Procurement of Canister } \\
\text { Fill/Decon System of full-scale } \\
\text { mockup can be proof-tested prior to } \\
\text { simulant testing. }\end{array}$ & $\begin{array}{l}\text { - Remote canister filling and } \\
\text { closure operations are } \\
\text { mechanically complex, remote } \\
\text { decontamination may also be } \\
\text { required. } \\
\text { - Proof test shows design changes } \\
\text { required to meet performance } \\
\text { requirements. } \\
\text { - Results of proof test could } \\
\text { cause redesign that affects } \\
\text { project baseline. }\end{array}$ \\
\hline IWTU-021 & $\begin{array}{l}\text { Process Off-Gas Filter Performance. } \\
\text { Closed - Risk Mitigated by Test } \\
\text { Program. }\end{array}$ & $\begin{array}{l}\text { - Critical Path } \\
\text { Schedule } \\
\text { slippage } \\
\text { - Cost increase to } \\
\text { redesign }\end{array}$ & Technical & $\begin{array}{l}\text { - Simulation } \\
\text { - Function }\end{array}$ & None & None \\
\hline IWTU-022 & $\begin{array}{l}\text { Mercury emissions higher than expected } \\
\text { at Hazen. Closed - Risk Mitigated by } \\
\text { Test Program. }\end{array}$ & $\begin{array}{l}\text { Cost increase to } \\
\text { redesign }\end{array}$ & $\begin{array}{l}\text { - Technical } \\
\text { - External }\end{array}$ & $\begin{array}{l}\text { - Simulation } \\
\text { - Function }\end{array}$ & $\begin{array}{l}\text { - IWTU Mercury abatement system } \\
\text { design is more conservative than } \\
\text { Hazen design and will provide more } \\
\text { efficient mercury removal. } \\
\text { - Results from Carbonate Phase } 2 \\
\text { testing demonstrated required } \\
\text { mercury removal at Hazen. }\end{array}$ & None \\
\hline IWTU-023 & $\begin{array}{l}\text { Quality Assurance not adequately } \\
\text { implemented. Closed - Risk Mitigated } \\
\text { by QA Planning/Program. }\end{array}$ & $\begin{array}{l}\text { Critical Path } \\
\text { Schedule slippage }\end{array}$ & $\begin{array}{l}\text { - Program } \\
\text { - Technical } \\
\text { - Internal }\end{array}$ & $\begin{array}{l}\text { - Systems } \\
\text { Eng/Quality }\end{array}$ & None & None \\
\hline
\end{tabular}




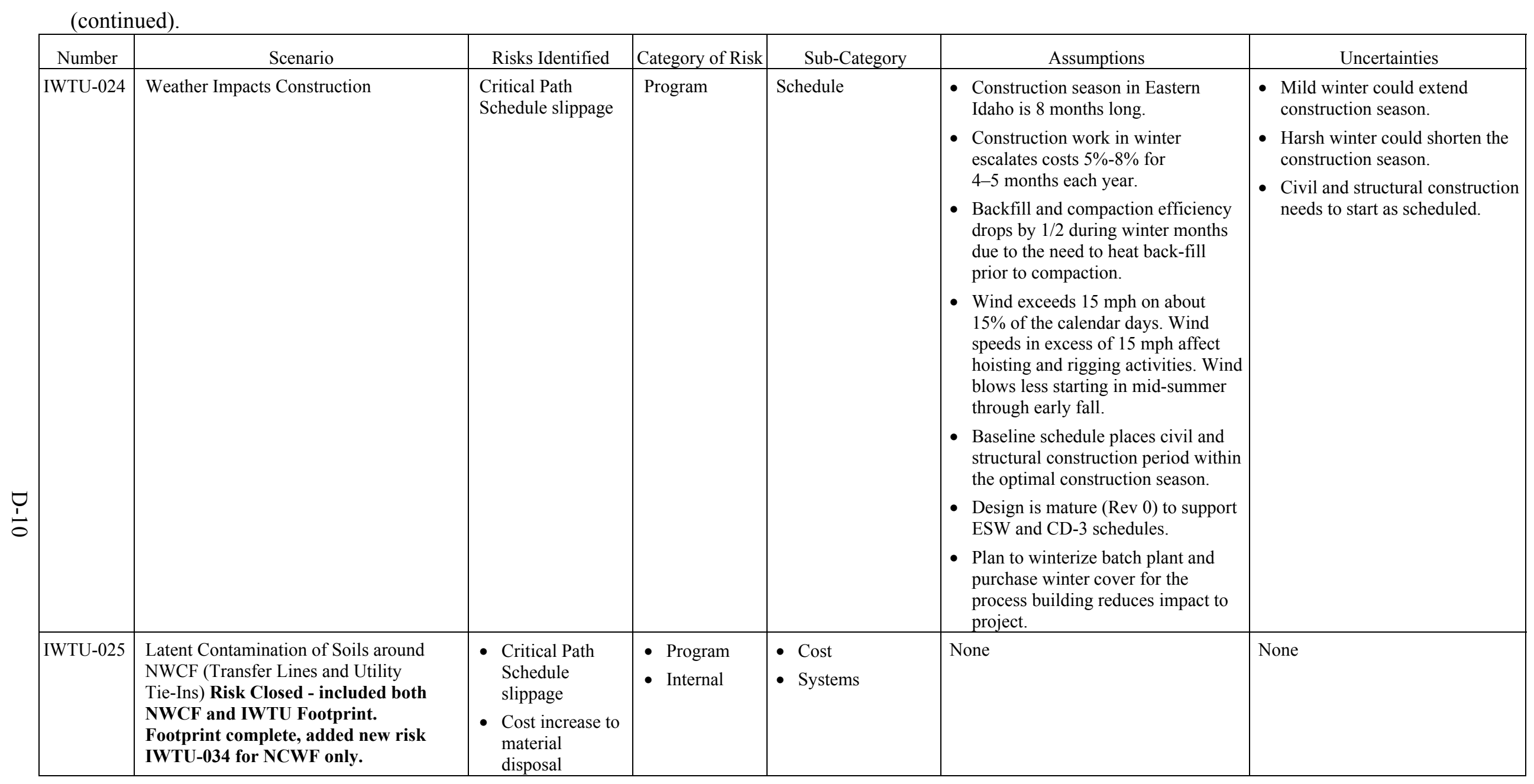




\begin{tabular}{|c|c|c|c|c|c|c|}
\hline Number & Scenario & Risks Identified & Category of Risk & Sub-Category & Assumptions & Uncertainties \\
\hline IWTU-026 & Limited Work Force for Construction & $\begin{array}{l}\text { - Critical Path } \\
\text { Schedule } \\
\text { slippage } \\
\text { - Cost Increase to } \\
\text { recruit } \\
\text { construction } \\
\text { staff }\end{array}$ & Program & Schedule & $\begin{array}{l}\text { - Labor forces required for IWTU } \\
\text { Construction are available to } \\
\text { support subcontractor's staffing } \\
\text { plan. } \\
\text { - By placing a single subcontract, } \\
\text { with a larger construction company, } \\
\text { the subcontractor will have the } \\
\text { necessary leverage to staff the labor } \\
\text { needs of the construction schedule. }\end{array}$ & $\begin{array}{l}\text { - Several years without major } \\
\text { construction in Idaho forced } \\
\text { workers to move elsewhere or } \\
\text { work away from home. } \\
\text { - Recently awarded ID State } \\
\text { Roadway construction could } \\
\text { utilize carpenters, ironworkers, } \\
\text { laborers, operators, and } \\
\text { finishers needed for IWTU. } \\
\text { - The number of fitters, } \\
\text { electricians, and other trades in } \\
\text { the area of the work may also } \\
\text { be limited. }\end{array}$ \\
\hline IWTU-027 & $\begin{array}{l}\text { Equipment Deliveries needed to support } \\
\text { construction schedule. New risk added } \\
\text { for } 6 \text { heavy lift skids. }\end{array}$ & $\begin{array}{l}\text { Critical Path } \\
\text { Schedule slippage }\end{array}$ & Program & $\begin{array}{l}\text { - Schedule } \\
\text { - Sequencing }\end{array}$ & $\begin{array}{l}\text { - Engineered equipment can be } \\
\text { fabricated and delivered in time to } \\
\text { support the construction schedule. } \\
\text { - Bulk Construction Materials can be } \\
\text { delivered to support construction } \\
\text { schedule. } \\
\text { - Construction Critical Path can be } \\
\text { re-sequenced to support delays in } \\
\text { deliveries. }\end{array}$ & $\begin{array}{l}\text { - The timeliness and sequence of } \\
\text { equipment deliveries may not } \\
\text { support construction schedule. } \\
\text { - The timeliness and sequence of } \\
\text { bulk materials may not support } \\
\text { construction schedule. }\end{array}$ \\
\hline IWTU-028 & $\begin{array}{l}\text { Simplied soil-structure interaction (SSI) } \\
\text { analysis is non-conservative. Risk } \\
\text { Realized - Full SSI Analysis is being } \\
\text { performed prior to CD-3. }\end{array}$ & $\begin{array}{l}\text { - Critical Path } \\
\text { Schedule } \\
\text { slippage } \\
\text { - } \begin{array}{l}\text { Cost increase to } \\
\text { redesign }\end{array}\end{array}$ & $\begin{array}{l}\text { - Program } \\
\text { - Technical }\end{array}$ & $\begin{array}{l}\text { - } \text { Cost } \\
\text { - Design/Eng } \\
\text { - } \text { Modeling } \\
\text { - Systems }\end{array}$ & None & None \\
\hline
\end{tabular}




\begin{tabular}{|c|c|c|c|c|c|c|}
\hline Number & Scenario & Risks Identified & Category of Risk & Sub-Category & Assumptions & Uncertainties \\
\hline IWTU-029 & $\begin{array}{l}\text { Controls to prevent GAC Exothermic } \\
\text { Reaction not sufficiently developed. }\end{array}$ & $\begin{array}{l}\text { - Critical Path } \\
\text { Schedule } \\
\text { slippage } \\
\text { - Cost increase to } \\
\text { redesign }\end{array}$ & Technical & $\begin{array}{l}\text { - Design/Eng } \\
\text { - Function }\end{array}$ & $\begin{array}{l}\text { - Heat up of the GAC bed after CRR } \\
\text { at normal operating temperatures } \\
\text { prevents hot spots from occurring. } \\
\text { This was successfully demonstrated } \\
\text { during Carbonate Phase } 2 \text { Testing. } \\
\text { - Since IWTU does not use a natural } \\
\text { gas auxiliary heat source in the } \\
\text { CRR, the fuel source available at } \\
\text { Hazen will not be present in the } \\
\text { IWTU. } \\
\text { - The normal operating temperatures } \\
\text { of the GAC Bed will be far below } \\
\text { ignition temperatures of GAC. } \\
\text { - No additional testing of the ESTD } \\
\text { mercury adsorber or off-gas system } \\
\text { is required. }\end{array}$ & $\begin{array}{l}\text { - Mechanism to create hot spot } \\
\text { has not been confirmed. } \\
\text { - Report, when issued, is not } \\
\text { accepted by DOE }\end{array}$ \\
\hline IWTU-030 & IWTU Cost Estimate Accuracy & $\begin{array}{l}\text { Proposed baseline } \\
\text { not bounding for } \\
\text { project execution }\end{array}$ & Program & $\begin{array}{l}\text { - } \text { Cost } \\
\text { - Budget }\end{array}$ & $\begin{array}{l}\text { The Performance Baseline is bounding } \\
\text { for execution of the project. }\end{array}$ & $\begin{array}{l}\text { - Maturity of preliminary design } \\
\text { vs. final design. } \\
\text { - Required changes identified by } \\
\text { test program (Mock-up } \\
\text { Testing). } \\
\text { - Labor and material availability } \\
\text { uncertainties are adequately } \\
\text { addresses by IWTU-017 and } \\
\text { IWTU-026. }\end{array}$ \\
\hline
\end{tabular}




\begin{tabular}{|c|c|c|c|c|c|c|}
\hline Number & Scenario & Risks Identified & Category of Risk & Sub-Category & Assumptions & Uncertainties \\
\hline IWTU-031 & $\begin{array}{l}\text { Scaling observed in DMR during Hazen } \\
\text { testing. }\end{array}$ & & Technical & $\begin{array}{ll}\text { - } & \text { Design/Eng } \\
\text { - } & \text { Field Test } \\
\text { - } & \text { Simulation }\end{array}$ & $\begin{array}{l}\text { - Lab Scale testing, planned for the } \\
\text { project to identify cause of scaling, } \\
\text { will demonstrate mitigation } \\
\text { capability for the IWTU. } \\
\text { - Scaling is not detrimental to the } \\
\text { operation of the IWTU. } \\
\text { - Use of washed coal, having low } \\
\text { sulfur content, will keep scale from } \\
\text { forming. }\end{array}$ & $\begin{array}{l}\text { - Rate of scale formation is } \\
\text { unknown. } \\
\text { - Scaling may lead to blockage of } \\
\text { instrumentation sensor within } \\
\text { the DMR. } \\
\text { - Use of washed coal having low } \\
\text { sulfur content may not prevent } \\
\text { scale from forming. }\end{array}$ \\
\hline IWTU-032 & $\begin{array}{l}\text { NWCF Facility Modifications compete } \\
\text { with Remote Handled TRU and Filter } \\
\text { Leach Projects for same area at the same } \\
\text { time. }\end{array}$ & $\begin{array}{l}\text { Critical Path } \\
\text { Schedule slippage }\end{array}$ & Internal & $\begin{array}{l}\text { - Management } \\
\text { - Systems } \\
\text { - Organizational }\end{array}$ & $\begin{array}{l}\text { - Close coordination of activities will } \\
\text { successfully allow integration of } \\
\text { numerous projects in the same area. }\end{array}$ & $\begin{array}{l}\text { Schedule performance by both } \\
\text { IWTU and other projects. }\end{array}$ \\
\hline IWTU-033 & $\begin{array}{l}\text { Fabrication of Process Vessels and Skids } \\
\text { does not meet Construction Schedule. }\end{array}$ & $\begin{array}{l}\text { Critical Path } \\
\text { Schedule slippage }\end{array}$ & Program & $\begin{array}{l}\text { - Schedule } \\
\text { - Sequencing }\end{array}$ & $\begin{array}{l}\text { - Engineered equipment can be } \\
\text { fabricated and delivered in time to } \\
\text { support the construction schedule. } \\
\text { - Construction Critical Path can be } \\
\text { re-sequenced to support delays in } \\
\text { deliveries. }\end{array}$ & $\begin{array}{l}\text { The timeliness and sequence of } \\
\text { equipment deliveries may not } \\
\text { support construction schedule. }\end{array}$ \\
\hline IWTU-034 & $\begin{array}{l}\text { Latent Contamination of Soils around } \\
\text { NWCF (Transfer Lines and Utility } \\
\text { Tie-Ins). }\end{array}$ & $\begin{array}{l}\text { - Critical Path } \\
\text { Schedule } \\
\text { slippage } \\
\text { - Cost increase to } \\
\text { material } \\
\text { disposal }\end{array}$ & $\begin{array}{l}\text { - Program } \\
\text { - Internal }\end{array}$ & $\begin{array}{l}\text { - Cost } \\
\text { - Systems }\end{array}$ & $\begin{array}{l}\text { - Soil around construction area and } \\
\text { NWCF is potentially radiologically } \\
\text { contaminated. } \\
\text { - If contamination is found, the } \\
\text { construction estimate includes } \\
\text { sufficient cost allocation ( } 5 \% \text { of } \\
\text { material excavated will be disposed } \\
\text { of at ICDF) to cover the cost of } \\
\text { disposal. }\end{array}$ & $\begin{array}{l}\text { - Latent contamination and } \\
\text { equipment from legacy } \\
\text { operations may have } \\
\text { contaminated soils around the } \\
\text { NWCF. } \\
\text { - Contamination may be } \\
\text { discovered during excavation. } \\
\text { Lightly contaminated material } \\
\text { is dispositioned at ICDF. More } \\
\text { highly contaminated material is } \\
\text { dispositioned at other locations, } \\
\text { Costs increase above budget } \\
\text { estimate cost allocation. }\end{array}$ \\
\hline $\mathrm{N} / \mathrm{A}$ & $\begin{array}{l}\text { INTEC Facility Interfaces. Not } \\
\text { Evaluated - INTEC operated by same } \\
\text { contractor as IWTU. }\end{array}$ & $\begin{array}{l}\text { Critical Path } \\
\text { Schedule slippage }\end{array}$ & Internal & $\begin{array}{l}\text { - Management } \\
\text { - Systems } \\
\text { - Organizational }\end{array}$ & $\begin{array}{l}\text { Construction will be performed by a } \\
\text { subcontractor in accordance with } \\
\text { their plans and procedures. } \\
\text { - Construction area will be outside } \\
\text { INTEC Fence and treated as Green } \\
\text { Field Construction. }\end{array}$ & $\begin{array}{l}\text { Some INTEC Procedures may } \\
\text { apply at interfaces to various } \\
\text { groups within CWI. }\end{array}$ \\
\hline
\end{tabular}




\begin{tabular}{|c|c|c|c|c|c|c|}
\hline Number & Scenario & Risks Identified & Category of Risk & Sub-Category & Assumptions & Uncertainties \\
\hline $\mathrm{N} / \mathrm{A}$ & $\begin{array}{l}\text { Issuance of Documents to Construction - } \\
\text { Not Evaluated - Design being } \\
\text { performed by a CWI affiliate. }\end{array}$ & $\begin{array}{l}\text { Critical Path } \\
\text { Schedule slippage }\end{array}$ & $\begin{array}{l}\text { - Internal } \\
\text { - Technical }\end{array}$ & $\begin{array}{l}\text { - Organizational } \\
\text { - Design/Eng }\end{array}$ & $\begin{array}{l}\text { Documents required to support } \\
\text { construction are issued in time to } \\
\text { support the construction schedule. } \\
\text { - Documents required to support } \\
\text { construction have been identified } \\
\text { and are scheduled to be released to } \\
\text { support the construction schedule. } \\
\text { - Documents issued to construction } \\
\text { are mature and accurate. }\end{array}$ & $\begin{array}{l}\text { Documents required for } \\
\text { construction are not issued in a } \\
\text { timely manner. } \\
\text { - Documents required for } \\
\text { construction are not mature or } \\
\text { contain errors. }\end{array}$ \\
\hline $\mathrm{N} / \mathrm{A}$ & $\begin{array}{l}\text { Just in Time Deliveries to Construction. } \\
\text { Not Evaluated - Construction will be } \\
\text { by a Subcontractor or CWI affiliate. }\end{array}$ & $\begin{array}{l}\text { Critical Path } \\
\text { Schedule slippage }\end{array}$ & $\begin{array}{l}\text { - Program } \\
\text { - Internal }\end{array}$ & $\begin{array}{l}\text { - Schedule } \\
\text { - Resources }\end{array}$ & $\begin{array}{l}\text { - Construction will be performed by a } \\
\text { single subcontractor. } \\
\text { - By placing the construction } \\
\text { subcontract with a single } \\
\text { subcontractor, the list possible } \\
\text { interested companies will be limited } \\
\text { to larger firms who offer the full } \\
\text { array of services including } \\
\text { procurement, delivery, and } \\
\text { warehousing. }\end{array}$ & $\begin{array}{l}\text { - Constructor may not be able to } \\
\text { provide procurement, delivery, } \\
\text { and/or warehousing services. }\end{array}$ \\
\hline N/A & $\begin{array}{l}\text { Funding Shortfall. Not Evaluated - } \\
\text { congressional funding changes are } \\
\text { considered directed changes per } \\
\text { DOE O 413.3A. }\end{array}$ & $\begin{array}{l}\text { Critical Path } \\
\text { Schedule slippage }\end{array}$ & $\begin{array}{l}\text { - Program } \\
\text { - External }\end{array}$ & $\begin{array}{l}\text { - Budget } \\
\text { - Political }\end{array}$ & $\begin{array}{l}\text { After approval of the performance } \\
\text { baseline, the funding will be provided } \\
\text { in accordance with the Project Data } \\
\text { Sheet. }\end{array}$ & $\begin{array}{l}\text { Political turmoil and wars may } \\
\text { effect funding and may undermine } \\
\text { the assumption. }\end{array}$ \\
\hline N/A & $\begin{array}{l}\text { Union Strikes. Not Evaluated - Site } \\
\text { Stabilization Agreement prohibits } \\
\text { strikes by organized labor. }\end{array}$ & $\begin{array}{l}\text { Critical Path } \\
\text { Schedule slippage }\end{array}$ & - Program & - Schedule & $\begin{array}{l}\text { - Site Stabilization Agreement } \\
\text { prohibits strikes by organized labor } \\
\text { and lockouts by management. } \\
\text { - Site Stabilization Agreement applies } \\
\text { to Construction Subcontract. }\end{array}$ & None \\
\hline N/A & $\begin{array}{l}\text { DOE delays approval of Safety Basis. } \\
\text { Not Evaluated - Contract requires } \\
\text { review within } 30 \text { days. }\end{array}$ & $\begin{array}{l}\text { Critical Path } \\
\text { Schedule slippage }\end{array}$ & $\begin{array}{l}\text { - External } \\
\text { - Internal }\end{array}$ & $\begin{array}{l}\text { - Requirements } \\
\text { - Organizational }\end{array}$ & $\begin{array}{l}\text { - Contract requires review with-in } \\
30 \text { days. } \\
\text { - Approval is by DOE-ID not } \\
\text { DOE-HQ. } \\
\text { - Safety Basis document transmitted } \\
\text { to DOE-ID for review/approval is } \\
\text { mature and meets expectations of } \\
\text { DOE-ID. } \\
\text { - Nuclear Safety continues to involve } \\
\text { IPT in updates to PDSA and draft of } \\
\text { FDSA }\end{array}$ & $\begin{array}{l}\text { - Contract may be revised. } \\
\text { - Approval authority may change } \\
\text { from DOE-ID to DOE-HQ. } \\
\text { - Safety Basis Document is not } \\
\text { mature when delivered or does } \\
\text { not meet expectations. } \\
\text { - Nuclear Safety does not involve } \\
\text { IPT in updates to PDSA and } \\
\text { draft of FDSA }\end{array}$ \\
\hline
\end{tabular}




\begin{tabular}{|c|c|c|c|c|c|c|}
\hline Number & Scenario & Risks Identified & Category of Risk & Sub-Category & Assumptions & Uncertainties \\
\hline N/A & $\begin{array}{l}\text { Failure to implement Quality Assurance } \\
\text { programs results in un-acceptable } \\
\text { material, conditions, equipment or } \\
\text { services. Not Evaluated - QA Programs } \\
\text { in place with audits and surveillances } \\
\text { scheduled. }\end{array}$ & $\begin{array}{l}\text { - Critical Path } \\
\text { Schedule } \\
\text { slippage } \\
\text { - Cost increase }\end{array}$ & $\begin{array}{l}\text { - Program } \\
\text { - Technical } \\
\text { - Internal }\end{array}$ & $\begin{array}{l}\text { - Systems } \\
\text { Eng/Quality }\end{array}$ & $\begin{array}{l}\text { - Project Program and Procedures are } \\
\text { flowed down to partners and Subs. } \\
\text { - Programs and Procedures are } \\
\text { implemented by partners and subs. } \\
\text { - Vendors are capable of supplying } \\
\text { products that meet QA } \\
\text { requirements. } \\
\text { - Oversight activities by CWI and } \\
\text { affiliates will minimize occurrence } \\
\text { of defective items }\end{array}$ & $\begin{array}{l}\text { - Vendors are not capable of } \\
\text { supplying products that meet } \\
\text { QA requirements }\end{array}$ \\
\hline $\mathrm{N} / \mathrm{A}$ & $\begin{array}{l}10 \text { CFR } 851 \text { approval for CWI may delay } \\
\text { the critical path schedule. Not Evaluated } \\
\text { - CWI Plan approved in May 2007. }\end{array}$ & $\begin{array}{l}\text { Critical Path } \\
\text { Schedule slippage }\end{array}$ & $\begin{array}{l}\text { - External } \\
\text { - Internal }\end{array}$ & Requirements & $\begin{array}{l}\text { - Constructor will follow the CWI } \\
10 \text { CFR } 851 \text { Plan. } \\
\text { - CWI reviews and approves the } \\
\text { construction subcontractor's } \\
10 \text { CRF } 851 \text { compliant program. }\end{array}$ & $\begin{array}{l}\text { Approval of the CWI Plan by DOE } \\
\text { will be by } 5-26-07 \text { to support the } \\
\text { Construction Schedule. }\end{array}$ \\
\hline N/A & $\begin{array}{l}\text { Concerns raised by the DNFSB in the } \\
\text { CD- } 2 / 3 \text { B acknowledgement Approval } \\
\text { Letter dated January } 24,2007 \text {, are not } \\
\text { resolved prior to CD-3. Not Evaluated - } \\
\mathbf{3} \text { concerns covered by existing } \\
\text { evaluated risks and } 2 \text { concerns, routine } \\
\text { sampling and PDSA updates, planned } \\
\text { on project schedule. }\end{array}$ & $\begin{array}{l}\text { - Critical Path } \\
\text { Schedule } \\
\text { slippage } \\
\text { - Cost increase } \\
\text { due to redesign }\end{array}$ & - External & $\begin{array}{l}\text { - Requirements } \\
\text { - Political }\end{array}$ & $\begin{array}{l}\text { - Frequent and ongoing } \\
\text { communications with EM and } \\
\text { DNFSB will resolve concerns prior } \\
\text { to CD-3. }\end{array}$ & $\begin{array}{l}\text { Requirements for Safety } \\
\text { Significant SSCs are not as } \\
\text { clearly defined as requirements } \\
\text { for Safety Class SSCs. }\end{array}$ \\
\hline
\end{tabular}


D-16 
Appendix E

\section{Risk Categories}


D-2 


\section{Appendix E}

\section{Risk Categories}

Potential areas of consideration for risk include, but are not limited to, the categories and subcategories described in the following sections.

Note, each risk category that is used by a program should be broken into at least two aspects, in other words, two different perspectives, to eliminate the potential of one risk dominating the planning process. If broken into smaller, more manageable elements, the risk potential and impact are spread, thus reducing the impact on the planning and executing processes.

Risk categories are not comprehensive and are not intended as such. Examples given below are meant only as guidance and are not comprehensive or prescriptive. The guidance is meant to provoke relevant thought processes.

\section{E-1. PROGRAM CATEGORIES}

1. Cost: risk due to unknowns or potentially weak cost estimate.

2. Schedule: risk due to inadequate schedule being allocated to a task, activity due to unavailability of human resources, or schedule failure due to delayed procurement action.

3. Budget: risk due to budget reduction due to federal funding being cut for program or inadequate budget planning due to schedule unknowns.

4. Concurrency: risk due to planning error regarding tasks that must occur concurrently, change in availability of various resources to allow for tasks, or activities to occur concurrently.

5. Sequencing: risk due to failure to deliver or communicate late delivery of task product to next performer per schedule, thus resulting in cascading schedule risk being incurred.

6. Scope: risk due to not fully understanding the scope or not adequately defining program metrics to allow various program measurement tools to adequately program issues.

\section{E-2. TECHNICAL CATEGORIES}

1. Design/engineering: risk due to inadequate requirements identification or incorporation into existing facility with inadequate as-built designs.

2. Function: risk due to commercial-off-the-shelf parts not functioning as projected in apparatus or chemical fails to interact with biological simulant as predicted due to environmental conditions.

3. Integration: risk due to interference caused by interaction of two technologies in close proximity to one another.

4. State of base technology development: risk due to finding that base technology upon which evolving technology is based does not perform as described. 
5. Development fabrication: risk due to inability of designated fabrication shop to fabricate necessary parts for the development of targeted technology or failure to be within tolerance of technology design specifications causing failure.

6. Modeling: risk due to possible inadequacies of design modeling capability or inability of design modeling function to adequately address material issues.

7. Simulation: risk due to variables not being accounted for in the simulation activity such as bench-scale or computer simulation or inadequacy of simulation activity to address existing field conditions, thus not being able to further identify risks.

8. Field test and evaluation: risk due to failure to test and evaluate under actual field conditions that will be present during actual use of the technology or lack of fully understanding the results of a field test leading to erroneous tolerance limits being placed upon the technology.

9. Operational: risk due to design issue resulting from failure to understand the operational requirement set.

10. Environmental: risk due to issues resulting from technical process with unclear end-state that produces a waste stream or secondary waste generated that proves to be a handling issue for the end-user.

11. Systems engineering/Quality Assurance: risk due to inadequate cascade of requirements and/or inadequate reviews being done at critical junctures in the life-cycle of program elements, individual projects, or failure to maintain records that are current in regard to regulatory requirements.

\section{E-3. EXTERNAL CATEGORIES}

1. Logistics/support: risk due to failure to adequately plan procurement officers necessary to support completion of procurements for bench-scale.

2. Threat: risk due to criminal activity as in property destruction at a field test site.

3. Market Threat: risk due to competition from other technology developers.

4. Capability of the research and development performers: risk due to issues regarding available skills expertise, capabilities necessary to perform task at a laboratory, or inability of technology developer to attain necessary training to perform task.

5. Stakeholders: risk due to failure to identify a stakeholder group causing issues with support for the program or project, or lack of understanding of requirements for technology from end-user or impacted stakeholder community.

6. Requirements: risk due to not identifying requirements for the technology use in the field or risk of not fully understanding a requirement such as the need for material use that will be under a five pound limit.

7. Operational: risk due to design issue resulting from failure to understand operation requirement that buttons for initiating technology process must be large enough to allow a gloved first responder to use technology in the field or lack of understanding the type of read-out necessary for immediate danger to be fully understood in the field. 
8. Organizational: risk due to failure to foresee impact on program or project as a result of an organizational change in management at a laboratory or understanding full impact on the program or project when a reorganization change has occurred impacting availability of resources to the program or project.

9. Political: risk due to not fully analyzing the impact on program if a change in party power occurs in Congress or failure to understand impact if change in appointees occur within Department of Energy if party in power changes.

10. Systems such as health, safety, and environment: risk due to failure to understand the health, safety, and environment requirements imposed upon activities or tasks due to location of the technology test and evaluation or failure to fully understand the impact from safety, health, and environment requirements imposed within a facility where work is being performed.

\section{E-4. INTERNAL CATEGORIES}

1. Availability of resources: risk due to lack of necessary availability of required performers or budget due to failure to adequately determine and plan contingency funding.

2. Management: risk due to inadequate champion within management for program.

3. Stakeholders: risk due to failure of identification of an internal stakeholder group (end-user internal to the organization) causing issues with support for the program or project, or lack of understanding of requirements for technology from internal organization end-user community.

4. Organizational: risk due to failure to foresee impact on program or project as a result of an organizational change in management at a laboratory, or understanding full impact on the program or project when a reorganization change has occurred impacting resources to the program or project.

5. Systems such as health, safety, and environment: risk due to failure to understand the organizational internal health and safety requirements imposed upon activities or tasks due to location of the technology test and evaluation or failure to fully understand the impact from organizationally (beyond regulatory) imposed safety and health requirements imposed within a facility where work is being performed. 